\title{
A CULPA É DO EUZÉBIO DE QUEIROZ?
}

\author{
Maria Sueli Rodrigues de Sousa ${ }^{1}$ \\ Maria Jeanete Fortes Silva ${ }^{2}$
}

\section{RESUMO}

O presente artigo analisa o feito de Euzébio de Queiroz na Lei de Terras e as formas como as instituições de justiça tratam as pessoas oriundas da exclusão produzida pela referida lei, para tematizar e demonstrar que essa questão tem reflexos sobre outra não tão debatida: a não interpelação do referido sujeito-alvo como pertencente ao pacto de nação. Noutras palavras: o sujeito negro tende a não ser tratado com a consideração que um autor da constituição merece. A pergunta orientadora é: como enfrentar o despertencimento constitucional de pessoas empobrecidas e negras no âmbito do sistema de justiça criminal? Com a indicação de denunciar as violações, na perspectiva de construir outro entendimento de nação. O texto foi produzido como revisão de literatura por meio de categorias analíticas orientadoras da produção do itinerário discursivo. O resultado foi um diagnóstico da atuação do sistema criminal, cuja discussão mirou a estrutura que serve a invisibilizar os direitos fundamentais no sistema criminalizador, indicando modos de enfrentamentos com a força de construírem outros entendimentos de comunidade política, constitucionalismo e pacto de nação que sirvam, por sua vez, a promover o sentido de que todos os nacionais são iguais pertencentes e assim interpelados devem ser.

PALAVRAS-CHAVE: constituição, colonialidade, racismo, encarceramento em massa, sujeito constitucional.

\footnotetext{
${ }^{1}$ Possui graduação em Ciências Sociais pela Universidade Federal do Piaú (1996) e Direito pela Universidade Estadual do Piauí (2003), advogada, mestrado em Desenvolvimento e Meio Ambiente pela Universidade Federal do Piauí (2005), é doutora em Direito, Estado e Constituição pela Universidade de Brasília (2009), com estágio pós doutoral pelo PNPD - Programa Nacional de Pós Doutorado, na Universidade Federal Rural do Rio de Janeiro, junto ao Programa de Pós-Graduação em Educação, Contextos Contemporâneos e Demandas Populares (PPGEduc). Tem experiência na área de Direito, Sociologia e Antropologia, com ênfase em teoria do Direito, Sociologia Jurídica, Antropologia Jurídica, Direito Ambiental e Socioambiental, Direito Constitucional, atuando, principalmente, nos seguintes temas: pesquisa empírica com direito constitucional, direito socioambiental, direito territorial, direitos humanos, relação cultura e natureza, populações tradicionais e quilombolas, convivência com o semi-árido e questões étnico-raciais. É professora Asoociada da Universidade Federal do Piaú, lotada no Departamento de Ciências Jurídicas - DCJ, no Programa de Pós-Graduação em Sociologia, no Programa de Pós Graduação em Gestão Pública, no Núcleo de Pesquisa sobre Africanidades e Afrodescendência - IFARADÁ e do grupo de pesquisa direitos humanos e cidadania - DiHuCi. Universidade Federal do Piaú -Brasil. ORCID iD: https://orcid.org/0000-0003-4611-2262 Lattes: http://lattes.cnpq.br/5572267892704240 E-mail:

${ }^{2}$ Bacharel em Direito. Mestre em Políticas Públicas pela Universidade Federal do Piauí. Atualmente é defensora pública $3^{\mathrm{a}}$ classe - Defensoria Pública. Tem experiência na área de Direito, com ênfase em Direito Penal e Direito Processual Penal. Instituição: ORCID iD: Lattes: http://lattes.cnpq.br/6084298911097293

Email:
} 


\section{INTRODUÇÃO}

Este texto foi produzido e tecido por meio de pertencimentos sociais e acadêmicos no âmbito de um projeto que está sendo realizado em parceria entre uma instituição de pesquisa e defensorias públicas de dois Estados. Portanto, de dois lugares de pertencimento partiu a reflexão: o ensino jurídico e a defensoria pública.

A experiência da defensoria conta com dezessete anos, especificamente, com atuação na defesa dos direitos dos sujeitos que tendem a ser alvos do sistema de justiça criminal brasileiro, quais sejam, pessoas empobrecidas e negras. Essa atuação é testemunha de que a parte do sistema que dispõe do dever constitucional, extraído do direito social fundamental à segurança pública, tende a agir teleologicamente, quase nunca, deontologicamente ${ }^{3}$.

A experiência na docência e na pesquisa jurídica, por sua vez, se dá numa universidade pública, num grupo de pesquisa e extensão em direitos humanos e cidadania, que conta com dez anos no desenvolvimento de pesquisa sobre violação de direitos fundamentais por políticas estatais de desenvolvimento. Nesse caso, o testemunho é de que, ainda quando se trate do direito fundamental à propriedade, esse parece ser efetivamente garantido somente aos grandes: aos pequenos proprietários, cujo perfil seja de agricultor familiar, esse não conta com nenhuma proteção. Ao contrário disso, a grande propriedade, tudo pode, tudo é. E isso se dá com ampla cobertura ou proteção do poder judiciário.

Noutras palavras, o sistema de justiça tende a orientar a sua atuação, quase sempre, para alcançar determinados fins enfatizados como os da humanidade. Mas nem se precisa de muita atenção para notar que a humanidade também é determinada por interesses evidentemente não universais, não raro, o contrário disso, favorecendo determinados grupos, por conseguinte, negando a humanidade da maioria das pessoas.

Nesse viés, o texto evita tematizar a humanidade como categoria amorfa. Noutras palavras, evita tratá-la em termos universalistas para nela caber aqueles que, por parte do sistema de justiça criminal, concretamente, desconsiderados têm sido da condição de humanos, ou, no máximo, são tratados pelo referido sistema como pertencentes a uma categoria precarizada, ou rebaixada de humanidade, quais sejam esses, os não brancos e os não abastados.

Machado de Assis e Lima Barreto em suas obras dizem bem quem é este ser humano universal. O primeiro autor, além do sarcasmo marcante da sua obra, revela-se um vingador, dizendo esse homem

\footnotetext{
${ }^{3}$ Teleologia no sentido de agir interessadamente, desconectado dos deveres a serem cumpridos. A questão foi tematizada por Jeremy Bentham (1979) como forma de apresentar os desligamentos da atuação em sociedade do conjunto de deveres que cada um deve cumprir.
} 
como um medíocre necessário: em Machado, a farsa se impõe como método do ser humano universal, ou que pretenda ser um. Os protagonistas dos contos, o Medalhão (ASSIS, 1994) e Fulano (ASSIS, 1984), são a descrição literal dessa norma. Bentinho, em Dom Casmurro (ASSIS, 1994), Quincas Borba (ASSIS, 1980) e outros tantos, das suas obras mais lidas, são marcados pela incapacidade de caminharem na direção desta que se impõe como a utopia de todos: a utopia do homem branco e abastado.

José Dias é o personagem, em Dom Casmurro, que funciona como metáfora de uma mediocridade superlativa que parece caracterizar os protagonistas nas obras machadianas: Dias não é escravo, mas também não é Senhor.

Lima Barreto matizou a sua revolta, em face dessa utopia parida pelo cinismo da tese do ser humano universal, ao tempo em que personagens como Policarpo Quaresma (BARRETO, 2005), que nem a cor, nem a classe da razão moderna tinha, desenhando um desfecho de frustração para o personagem que ousou sonhar.

Noutra obra, Recordações de Escrivão Isaías Caminha, Barreto (2017) põe de fora as vísceras desta razão, que se impõe como universalizante, com uma narrativa sobre o quão amoral há de ser o sujeito para percorrer o caminho que o levará a realizar-se como este ser humano universal.

Ambos os autores interditam o percurso. No primeiro, o destino alcançado é a mediocridade, no segundo, a morte na sarjeta.

Isso importa porque essa categoria (humanidade) foi sendo definida excluindo, histórica e culturalmente, a maior parte dos humanos e com base em critérios religiosos, éticos, morais, raciais e de classe (CIRINO, 1984) e até de gênero, sexualidade, geração. O que, por conseguinte, culminou num regramento jurídico destinado a proteger determinadas categorias e desamparar concretamente outras. Exemplo disso, temos a escravização de humanos arrastados de África para o Brasil e a questão indígena. Ambas revelam a desterritorialização como um tema fundamental para a compreensão de muitos problemas no Brasil, inclusive a violência. Essa que parece nos caracterizar como povo (RIBEIRO, 1995).

No que diz respeito às questões de raça e de classe, em termos de desumanização, ou coisificação do outro, o próprio Direito parece ter sido e continua sendo manejado como instrumento de fomento dessas questões numa espécie de simbiose: na época colonial, por exemplo, havia uma legislação que dava suporte à desidratação da condição de humano em face do sujeito escolhido para ser escravizado. E a escravidão era um sintoma desse manejo político-econômico (LARA, 2000). Hoje o sistema de justiça criminal faz a sua parte, afastando os indesejáveis, aquelas pessoas que não servem para serem recicladas, reencaixadas, realinhadas, retificadas (BAUMAN, 1998). 


\section{Quaestio Iuris}

vol.13, nº. 01, Riode Janeiro, 2020. pp.407-440

DOI: $10.12957 /$ rqi.2020.50969

No Brasil, a despeito de a constituição abrigar, formalmente, todos as pessoas como iguais pertencentes, o sistema de justiça criminal tende a tratar os seus notórios alvos como não pertencentes ao pacto de nação. $\mathrm{O}$ fato de o STF ter reconhecido o sistema carcerário brasileiro como inconstitucional, em si, uma vez que em Estado de Coisas Inconstitucional ${ }^{4}$, denota a validade dessa premissa, revelando o desleixo com os próprios postulados da teoria do direito moderno, ou pior, a desmoralização desses postulados

As questões que devem ser respondidas são: isso acontece porque a seletividade é imanente ao sistema, como diz Zaffaroni (1991), ou a seletividade é só instrumental, ou sintoma de uma causa mais estrutural, qual seja o racismo? A seletividade serve a explicar também o fato de que a maioria dos crimes de rua, contra o patrimônio, são praticados por pessoas empobrecidas e negras? Por sê-lo, o sistema tende, por causa disso, a ser mais severo e eficaz em face dos crimes contra o patrimônio e de rua, do ponto de vista da sua função não declarada (CIRINO, 1984), qual seja, a de afastar os indesejáveis? Há relação direta entre a questão de classe e a seletividade dos fatos a serem criminalizados e, principalmente, há mais empenho do sistema em escolher, perseguir e alcançar pessoas que praticam crimes de rua contra o patrimônio, tanto mais por que se encaixam na definição de indesejáveis?

Às perguntas acima a criminologia crítica tem respondido, descritivamente e de modo a denunciar que sim: o sistema de justiça criminal moderno foi inventado para afastar os indesejáveis. E o cálculo para considerar um sujeito como indesejável, na sociedade de consumidores (BAUMAN, 2011; 2015), é inversamente proporcional à matiz da identidade de consumidor que o sujeito pode exibir. Dado que, no Brasil, o empobrecimento parece recair, não coincidentemente, sobre pessoas não brancas e o racismo tempera o cinismo e a malvadeza deste critério.

Mas há outras questões mais agudas e que se aplicam, especificamente, ao Brasil: qual a relação entre tudo isso já exaustivamente denunciado e a opção política de abandonar as pessoas sujeitas à escravidão colonial, impedindo-as do acesso à terra, via lei de Terras em 1850, mantendo-as, portanto, tanto desterradas ${ }^{5}$, desde que trazidas à força de África para cá, quanto sem terras?

\footnotetext{
${ }^{4}$ ADPF 347, julgada em 09 de setembro de 2015 pelo Supremo tribunal Federal, demandado pelo PSOL - partido Socialismo e Liberdade, atestou o sistema carcerário brasileiro como inconstitucional pois, em síntese, é o que significa etiquetá-lo como Estado de Coisas Inconstitucional.

${ }^{5}$ No sentido de terem sido arrancadas à força de África, do lugar onde nasceram, destruindo-as ontologicamente, desfigurando as suas memórias, calando os sentidos que essas produzem, pois isso é condição não só para uma existência política, mas para a própria razão de existir. Território é útero, é razão para viver, é sentido, é memória, inclusive ancestral. É liberdade e, ao mesmo tempo, segurança. Sem ele, o vazio é do tamanho do absurdo. E esse nem por Deus poderia ser preenchido, pois o vazio, para aqueles que foram arrancados da sua mãe África, tendo isso o tamanho do Absurdo (CAMUS, 1999) só o nada poderia preenchê-lo, inclusive, porque o Deus que lhes foi apresentado também servia a justificar as misérias, consequências desse Absurdo ou dessa total ausência de sentidos.
} 


\section{Quaestio Iuris}

vol.13, nº.01, Riode Janeiro, 2020. pp.407-440

DOI: $10.12957 /$ rqi.2020.50969

Essa opção, no sentido imediato do termo, significou, ou não, concretamente, o fomento da miséria $^{6}$ delas, ou o desleixo com tal, dada a obviedade das consequências da regra contida no artigo $1^{\circ}$ da referida lei? Isso serviu, ou não, para travar o caminho das pessoas, formalmente libertas em 1888, na direção da cidadania e da dignidade sendo isso um sintoma que se reproduz até hoje?

A lei de Terras ajuda a compreender a interpelação dos herdeiros das misérias dessa escolha política como sujeitos não pertencentes ao pacto de nação a despeito de serem, como todos os nacionais, autores da constituição? Qual a estratégia político-jurídica que pode ser manejada para a superação deste agudo problema constitucional de outro modo que não seja o manejo político do corpo, entregando-o à uma revolução com armas, tão improvável, quanto ineficaz sem mudar-se as estruturas do ser, do poder e do saber alimentadas pelo projeto de modernidade?

Isso refletiria na face da nação brasileira que exibe a crueldade dessa má escolha, sob a forma atual do clamor por encarceramento, no lugar do clamor por justiça social? Essa má escolha pode ser atestada como causa da não interpelação hoje de pessoas empobrecidas e negras como pertencentes ao pacto de nação? De certa maneira, somos todos herdeiros dessa malvadeza originária e dos seus efeitos colaterais, inclusive, nos revelando, atualmente, como um povo desunido?

Considerando que a maior parte dessas questões, como dito, vêm sendo, exaustivamente, discutidas e, reiteradamente, respondidas pela crítica, melhor do que aqui se poderia fazê-lo, deveremos nos ater a analisar a questão menos debatida e que talvez se faça mais interessante, no momento, qual seja, a referente à esquizofrenização ${ }^{7}$ do sistema, no que diz respeito ao desleixo com a constituição no território da justiça criminal: qual seria a essência da falta de efetividade do direito constitucional em face da criminalização da pobreza e da negritude?

Antes de tentar responder, vale observar que a crítica, embriagada, ou pelo pessimismo, ou, para ser mais gentil e honesta, pela utopia dos abolicionismos penais, tende a não ver outro caminho que não seja a realização da referida utopia. Mas como se deve reconhecer que utopia é a caminhada, pois se trata daquilo que ainda não se realizou, por que então não considerar o constitucionalismo como o ponto de partida dessa caminhada, ou, no mínimo, uma boa companhia na direção do horizonte almejado? Esse, vale observar, é representado por um pacto onde acolhidas estejam todas as pessoas que se agasalham no colo de determinado espaço político-territorial, ainda mais considerando que os direitos fundamentais efetivados representam, no mínimo, uma brisa em meio à caldeira de Dante, essa representada, por sua vez, pela crueldade do sistema de justiça criminal.

\footnotetext{
${ }^{6}$ Mais amplo do que empobrecimento, pois miséria aqui pode ser lida como efeito colateral da sensação de $A b s u r d o$, da ausência de sentidos. Para melhor compreensão vê nota imediatamente anterior.

${ }^{7}$ Refere o manejo do Direito pelas instituições que o interpretam e o aplicam desconectando-o dos postulados que o sustentam como instrumento, tanto para manutenção da ordem, quanto para garantir a igualdade política, rompendo, por conseguinte, as engrenagens teóricas que justificam e explicam a sua funcionalidade jurídica e cultural.
} 
E finalmente, vale mais uma pergunta: o fato de o povo brasileiro guardar a tendência de avistar ao espelho um branco e abastado, ou desejar que assim o seja (FANON, 2015), jamais pretendendo, quando o sintoma não seja o da negação, de se vê como herdeiro do cabo de açoite, reconhecer a culpa ancestral que o provoque a implorar por misericórdia, em face dos herdeiros que sangraram ao movimento do braço de quem o manejava, ajuda a explicar o despertencimento que parece ser a causa de muitos dos nossos problemas?

O texto não dá conta de densamente responder a todas essas questões. E seria até arrogante pretendê-lo, mas lançar perguntas é o ponto de partida para as respostas, pois perguntar significa, no mínimo, constatar o problema, provocando, tanto a vontade de compreendê-lo, quanto de superá-lo.

A reflexão aqui apresentada, vale esclarecer, foi produzida a partir de revisão de leitura e discussão no grupo de pesquisa que realiza o projeto sobre violação de direitos fundamentais em processos da defensoria pública. A reflexão foi orientada pelo projeto com diagnóstico; garantia constitucionais e indicações para enfrentamento do problema.

Finalmente, a questão que o texto se propõe a responder é: como enfrentar o despertencimento constitucional de pessoas empobrecidas e negras no âmbito do sistema de justiça criminal? O pressuposto é o de que o enfrentamento à negação da condição de cidadania brasileira, por parte do sistema de justiça criminal, só pode ser realizado por meio da afirmação do pertencimento constitucional, tratando a constituição como a que produz a unidade e integridade do direito. $\mathrm{O}$ itinerário analítico do texto foi: diagnóstico; garantias constitucionais e indicações de enfrentamento ao problema.

\section{1 - DA MALVADEZA À NINGUENDADE}

A ontologia diagnosticada por Hegel (1992) e que sustentada era pela ideia de superioridade de alguns humanos sobre outros que, teoricamente, ainda não tinham evoluído para tal condição, por não ter consciência de sua superioridade, recebe o crédito epistemológico do evolucionismo darwinista (DARWIN, 2003). Esse, por sua vez, agarrou-se ao martelo interesseiro da ciência moderna, a quem foi destinado o papel de atestar o que era conhecimento, ou não; quem era humano, porque evoluído, ou não. E, finalmente, o que o sujeito precisava fazer para tornar-se um.

Considerando as questões acima, a discussão mergulha, emborcando-se sobre a ideia de que as preferências político-econômicas do Brasil, desde os tempos coloniais, até quando declarou o fim da escravidão, sempre passaram por selecionar quem era, ou não, gente, deixando a maior parte das pessoas de fora da casa do Direito, concretamente. E, por conseguinte, determinados sujeitos escolhidos têm sido, na modernidade, como alvos do sistema carcerário. 
Tal fenômeno se configura, com muita clareza, no sistema de justiça criminal brasileiro, manejado, aliás, inconstitucionalmente, para manter o bom funcionamento do sistema do ponto de vista da sua função dissimulada, ou não declarada, qual seja, a de afastar os indesejáveis, sujeitos diagnosticados como inviáveis para serem retificados, irrecicláveis: chorume (BAUMAN, 1998; 2001).

Assim parece ser porque pessoas empobrecidas e negras herdaram a ninguendade de que fala Ribeiro (1995), sendo em tempos coloniais tratadas como não humanos, ou ainda não humanos. No tempo atual, como indesejáveis.

Atualmente, na colonialidade (MIGNOLO, 2017) que incide sobre o Brasil e todas as nações não identificadas como Europa, e até desse lugar do colonizador, as pessoas negras, e/ou as não brancas $^{8}$, são tratadas como não pertencentes ao pacto de nação. Nessa linha, o sistema de justiça criminal serve bem a ilustrar que, a despeito de formalmente pertencerem ao pacto de nação, concretamente, não são tratadas como sujeitos constitucionais ${ }^{9}$. Vale esclarecer que Europa é menos um lugar que a geografia indica onde fica, sendo mais, na abordagem do texto, uma metáfora sobre quem dita como o mundo deve ser para a ela pertencer.

Inegável que herdamos uma dose embriagante da malvadeza que pariu a nação brasileira. Essa, num determinado momento em que, hegemonicamente, estava-se a discutir a abolição, somando-se isso às resistências em face da escravidão, desde sempre havidas por parte das suas vítimas, fez a opção político-econômica de manter o modelo de máxima espoliação (RIBEIRO, 1979), guiando os nossos sentidos de modo que continuássemos excluindo da casa da humanidade a maior parte dos humanos.

Noutras palavras: até hoje a condição para ser tratado como pertencente ao pacto de nação é ter evoluído para a condição humana. Mas para se chegar a esse lugar parece que a caminhada é sem

\footnotetext{
${ }^{8}$ No projeto sustentado pela colonialidade, ser branco transcende a literalidade do termo, servindo a expressar uma etiqueta de valor ao sujeito que se encaixa na ordem e na estética da modernidade eurocêntrica. Um termo vinculado também ao território, esse no sentido também, epistemológico, ontológico e de poder que amplia o sentido do que seja a categoria raça, mas que pode ser entendido, em suma, como o sujeito, cujos atributos pessoais, incluindo a classe a que pertence, o fazem menos suscetível à inferiorização.

${ }^{9}$ A Defensoria Pública do Estado do Maranhão, núcleo Timon, dispõe de um banco de dados permanentemente atualizado, chamado de monitoramento permanente, que começou em junho de 2019, cujos casos analisados retratam o absoluto desleixo do poder judiciário sobre as pessoas encarceradas no presídio regional em Timon/Ma, revelando tais que, a despeito da vara das execuções penais está devidamente instalada, toda a estrutura dela é utilizada para fazer funcionar a terceira vara criminal, criada, mas não instalada. E uma das explicações para tal é que o CNJ estabelece metas para as varas criminais, mas não o faz em relação às varas das execuções penais porque, uma vez condenada a pessoa, o sistema cumpriu a sua função obscura mais imediata, qual seja a de afasta um indesejável. O desleixo começa ainda na fase do juízo do conhecimento quando a pessoa já está condenada criminalmente, mas a Carta de Guia não é fabricada, ficando a pessoa na condição de inexistente processual, uma vez que sem a Carta de Guia, não há autos de execução, penal. E sem esses, sem nenhum dos direitos previstos na Constituição e na Lei de Execução Penal, pois não há processo para recepcionar os pedidos. Por causa disso, a Defensoria, em Timon, tem, estrategicamente, impetrou muitos Habeas Corpus individuais a fim de chamar atenção para o referido desleixo, além da relatoria de uma carta aberta, destinada à presidência e corregedoria do Tribunal de Justiça, assinada por mais de uma centena de entidades representantes da sociedade civil a fim de que o problema seja corrigido.
} 
fim, pois se trata de uma utopia que não foi inventada por nós, mas por aqueles que sempre se apresentam como se estivessem à nossa frente, uma vez que se dizem os únicos sabedores do caminho e do lugar onde chegar.

Isso parece significar que as pessoas tratadas como despertencentes tudo podem fazer, mas a esse lugar de evoluído jamais chegarão, considerando que são mais de quinhentos anos de caminhada, seguindo o caminho apontado e ainda são tratadas com desrespeito e desconsideração.

A primeira condição para ser humano por eles imposta era a de se tornar cristão. Os chamados sujeitos dos outros mundos, com algumas exceções, se tornaram cristãos e nada mudou; a outra exigência era e é a de estudar, aprender, nos termos impostos pela modernidade eurocêntrica, elas obedeceram e obedecem, mas, a despeito disso, permanecem sendo tratadas como não cidadãs; outra exigência, das mais importantes: a de produzirem e acumularem riquezas, ancoradas na ordem divina de reinar sobre toda a natureza, mas também está provado que nem isso lhes garante o tratamento com igual respeito e consideração.

Esse traço que nos parece característico continua sendo fomentado por aquilo que nos sopra aos ouvidos, a colonialidade - essa funcionando como ferramenta de desvalor que se insinua, nos seduzindo, narcotizando o nosso pensamento (MIGNOLO, 2014) para que nos encaixemos, ao máximo, na fórmula, ou no modo de vida, eurocentrado, cuja humanidade é representada pela imagem do homem único : branco e abastado. Valendo observar, nos termos de Quijano (2005), que o eurocentrismo não é uma questão geográfica, mas uma questão epistêmica. Nessa linha, trata-se também de uma questão ontológica.

A concepção sobre o que seja humano, desidratada de essencialidade ${ }^{10}$, mantendo-nos adestrados para construir a nossa vida, mirando o destino de nos tornarmos esse homem único ${ }^{11}$, retroalimenta o convencimento de que esse, tanto é o nosso destino fatal, quanto serve a revelar, para os mais atentos, as finalidades dessa sociedade projetada pelo eurocentrismo, quais sejam, a produção/acúmulo e consumo de riquezas (HEGEL, 1992). E, para tanto, não importa quantos e o que se tenha de aniquilar, ${ }^{12}$ esse destino realizado deve ser.

${ }^{10}$ Clarice Lispector. Conto: o Mineirinho revela o cinismo de se atribuir a Deus a responsabilidade de socorrer os
humanos em face dos seus dramas e tragédias de modo que o sujeito se sinta, tanto dispensado de fazer o que deveria
ser a sua parte, quanto bom porque invoca o Criador; quanto, mais ainda, cínico em face de sempre encontrar uma
justificativa na concepção de que a Deus a solução para o que ela chama de sonsice essencial: o cinismo da estratégia
revelada nesse discurso. Além disso, revela a iniquidade do ódio àquele sujeito que, como qualquer outro humano,
bastava um tiro para lhe fazer morrer, a partir daí, os outros tiros revelavam, para o narrador, a mais pura vontade de
matar.
${ }_{11}^{11}$ Branco e abastado e inventado, enfaticamente, pela modernidade
${ }^{12}$ Em Gênesis, no sexto dia, Deus inventou a penúltima criatura, o homem, a esse atribuindo o poder de Reinar sobre
todas as outras criaturas, ou invenções Dele. Exclusiva, ou, no mínimo, plenamente verbais são os humanos homens,
pois que a Eva, a última criatura, por exemplo, ficou sem nenhum verbo, uma vez que no verbo Reinar cabem todos
os outros verbos, por conseguinte, o distribuidor de verbos é o homem, na cosmovisão bíblica do velho testamento.
Isso serve a compreender a gênese do patriarcado que comanda quase todo o mundo até hoje. E a modernidade, vol.13, nº.01, Riode Janeiro, 2020.pp.407-440 
Acumular riquezas é considerado sintoma de realização do projeto referido e, por conseguinte, de alinhamento ao Deus inventado pelo ocidente. Por isso, o mínimo que devemos fazer é almejar esse destino que se apresenta a nós como Verbo fatal.

Um dos efeitos colaterais disso, no âmbito do sistema de justiça criminal, por exemplo, é a entrada na Casa do Direito de quem de fato seu dono é, pois somente em caso de falha na operação desse sistema, escolhido e perseguido vem a ser alguém, cujo território verbal avistado pode ser acima da base piramidal das hierarquias sociais, noutras palavras, um homem branco e abastado.

O habitante da Casa do Direito tende a ser esse sujeito que, dada a humanidade que lhe é atribuída, é para quem se escancaram as portas da casa do Direito. De fácil conclusão sobre quem entra nessa casa e em face de quem as suas portas quase sempre se fecham no Brasil. Ao primeiro, a constituição, pois ele, representando o homem único, é cidadão, porque, concretamente, pertencente ao pacto de nação. Ao segundo, na condição de alvo da penitência operada pelo sistema de justiça criminal, uma vez que não se encaixa nesse perfil, apenas o direito criminalizador-penal lhe cabe, pois só formalmente é considerado autor do referido pacto.

O sujeito-alvo do sistema de justiça criminal, como dito, é um indesejável (BAUMAN, 2011) para o mundo dos sistemas político e econômico. Esses colados numa dança simbiótica fúnebre, cerram as portas da casa do Direito para aquele. E assim é por motivos que o título posto neste texto explica. Sendo o fenômeno do encarceramento em massa só um dos seus sintomas mais funestos.

O sistema de justiça criminal precisando validar politicamente a falta de acesso dos seus alvos preferenciais à Casa do Direito, recorre à Moral, essa onde cabem todas as subjetividades que mais fáceis são de serem usadas para manejar as justificativas da falta de acesso à primeira. A ideia é afiar os dentes da sociedade em face do alvo preferencial do sistema de justiça criminal, o que é alimentado pelo poder comunicador, permanentemente, fazendo com que até os alvos tenham o mesmo entendimento.

A moral e as conveniências para o espírito particular transcendem, nesse quadro, o dever de agir, funcionalmente, por parte das instituições. Do ponto de vista dos postulados da teoria moderna do direito, cerrar a Casa do Direito para quem quer que seja, é proibido do ponto de vista constitucional, mas do ponto de vista da moral, não. E esta Moral é justificada, ardilosamente, como Direito.

Para ilustrar a premissa imediatamente acima, serve a constatação da raridade com que as normas constitucionais guiam as decisões tomadas no território da justiça criminal, uma vez que a

ancorada pelas sucessivas bulas papais que incentivaram Portugal e Espanha a cristianizar os chamados pagãos, além de arrogante, por parte da Igreja, "pode ser considerado a desculpa - retirada da culpa, portanto o estímulo para que o sujeito cruedelizasse e aniquilasse quem resistisse à ordem pretendida. Isso se configurou em método usado por todos os impérios coloniais subsequentes" Barnaby Rogerson (2004). O ardil do projeto de cristianização dos mundos serviu também para compor a imagem do sujeito ideal, qual seja, o homem branco e abastado inventado pelo ideal moderno. 
regra é o sistema operar, de modo bastante eficiente, para identificar, perseguir e, até alcançar, os seus alvos preferenciais, cumprindo a sua função dissimulada (CIRINO, 1984).

Tanto assim é que mais de $40 \%$ das quase 800 mil pessoas presas no Brasil ${ }^{13}$ ainda não foram julgadas. E o STF, por isso e, por muito mais que atinge também as pessoas que julgadas e condenadas já estão, admitiu o Estado de Coisas Inconstitucional como adjetivação e substantivação do sistema carcerário brasileiro.

Isso é o mesmo que dizer que o sistema penal está contaminado por inconstitucionalidades e que cabe ao o Estado corrigir o problema. E já se passaram cinco anos e nada. E o retrato de como funciona demonstra que o Estado não vai mudar nem em médio, nem em longo prazo. O que, por conseguinte, gera perplexidade, pois não lhe tendo sido imposto fazê-lo, na oportunidade da referida declaração de inconstitucionalidade pela corte superior, foi o mesmo que dizer que assim poderia permanecer. E isso parece, senão cínico, desleixado e desrespeitoso em face da constituição, ou do pacto nela inscrito, admitindo, quase expressamente, que a constituição é irrelevante.

Isso tende a esquizofrenizar a própria invenção que da modernidade ressoou, qual seja, a afirmação do Direito como instrumento universalizador para todos os seres humanos. Tal foi declarado, expressamente, depois da Segunda Guerra Mundial, por meio da Declaração Universal dos Direitos Humanos. Mas isso não conseguiu ultrapassar o campo da formalidade, pois, concretamente, a maior parte dos humanos, como dito, não consegue adentrar a casa do Direito.

Em verdade, a concretização da promessa de universalização nunca ocorreu, mas para garantir o engodo da declaração, tem sido necessária a permanente simulação histórica a que se prestou, desde sempre, se apresentando, agora, sem recato, a um discurso claramente mais farsesco ainda, pois as instituições, inclusive as que têm o dever de efetivar direitos, têm os sentidos pouco atentos para o cumprimento de tal dever, quando não serve a violá-los, principalmente, porque estão, mais do que nunca, genuflexas a uma ordem econômica perversa em favor de quem tudo vira mercadoria (BAUMAN, 1998).

Tudo isso ancorado no clamor por vingança contra os empobrecidos, no lugar do clamor ético por justiça social (BAUMAN, 1998). Isso que deveria ressoar do que está inscrito no artigo $3^{\circ}$, inciso III, da Constituição Federal como objetivo fundamental da república brasileira.

Na cidade de Timon, Estado do Maranhão, a Defensoria Pública dispõe de vários relatórios encaminhados às autoridades, reveladores de que em torno de $1 / 3$ das pessoas são transferidas para 0 Presídio Regional de lá, vindas de outras comarcas onde tramitou a ação penal em face delas e que culminou em condenação a pena privativa de liberdade. Elas são enviadas para a referida comarca sem, sequer, ter sido formada, como devido, a Carta de Guia no juízo de conhecimento, ou de origem.

\footnotetext{
${ }^{13}$ Dados do INFOPEN 2017
} 
Fatalmente isso significa que a pessoa é empurrada para o limbo dos direitos, pois tendo o juízo de conhecimento esgotado a sua jurisdição e sem a formação da referida Carta, processo de execução não há, por conseguinte, inviabilizada é, inevitavelmente, a possibilidade de manejo de qualquer pretensão de direitos previstos na Lei de Execução Penal, alinhados à ordem constitucional.

Em suma, nenhum dos direitos previstos na Lei de Exceção Penal poderá ser efetivado, dado que a pessoa inexiste processualmente. Isso denota que o sistema indiferente a eles, os tratando como inexistentes, os empurra para um grau de coisificação e de degradação que se por um lado a desculpa cristã pode ajudar a compreender, por outro, a teoria do direito nos força a reconhecer, com Giamberardino (2018), que se trata de um espaço que não compõe a metáfora contratualista e que, portanto, precisa se tornar jurisdicionalizado, pois ainda é puro arbítrio e de grotesca face.

E por que a violação sistemática de direitos, neste território da execução de pena privativa de liberdade, no Brasil, não parece espantar e indignar as pessoas, antes parecendo que desejável é? Muitas respostas certamente cabem, mas a que parece evidente pode ser coletada da história de crueldade que constitui a narrativa do povo brasileiro. Darcy Ribeiro (1995) nos conta muito claramente sobre como isso se deu e ainda se dá.

As misérias do processo penal (CARNELUTTI, 2013) devem ser consideradas a fim de permeabilizar as instituições e a sociedade sobre os sentidos da constituição. Isso de modo que a violação de direitos, por quem tem o dever de corrigi-la e preveni-la, não seja concebida por menos do que privar a pessoa do Sol, dotando-a, por conseguinte, de puro Absurdo (CAMUS, 2009).

Parece haver nesta indiferença nacional às crueldades do sistema carcerário brasileiro, ou pior ainda, no aparente desejo de fomentá-las, uma pulsão (FREUD, 2004) por malvadeza, pois testemunha-se, na sociedade brasileira, uma espécie de sadomasoquismo, sob a forma de clamor por mais padecimento e penitência. Não raro, aliás, testemunha-se, tragicamente, o grito de: "fora constituição", impulsionando quem tem o dever de corrigir e prevenir a dor da violação de direitos a alinhar-se a essa malvadeza, contrariando à própria função institucional, equivalendo tal ação a algo de esquizofrênico.

Refiro-me à figura do juiz que parece incompreender a sua própria função contramajoritária e contrahegemônica, talvez porque contaminado esteja com a dissonância cognitiva de uma sociedade sadomasoquista. Aliás, isso culmina na atração do juiz pelo canto da sereia da popularidade. Canto esse do qual ele deveria se sentir protegido ao mastro (ADORNO, 1982). Metaforicamente, esse mastro pode se revelar via concepção que postula a função do juiz como de natureza contramajoritária e contrahegemônica (GARAPON, 1999).

A percepção da maioria parece ser, ou a de que perde a condição de humana a pessoa escolhida, perseguida e alcançada pelo sistema de justiça criminal, ou humano ainda não sendo no sentido 
hegeliano (HEGEL, 1992). E a covardia de classificar e dar cor à Razão ${ }^{14}$ serviu para atestar a inexistência ou invalidar a existência de quem não pertencesse ao ocidente no sentido ontológico e epistemológico do termo.

E qual a dinâmica que explica esse fenômeno da indiferença? Bem! Primeiro os donos do Verbo (SARTRE, 2005) guiam, ardilosamente, a opinião pública a fim de que a hegemonia que protagonizam e representa os seus interesses mais parasitários (BAUMAN, 2015) se converta em opinião da maioria e, por conseguinte, se imprima como força, sem possibilidade de ser superada, pois, num segundo instante, tais interesses aparecem como sendo de todas as pessoas. Isso é um dos sintomas do fenômeno da colonialidade, dita por Mignolo (2017), como a face mais oculta, ou obscura, da modernidade.

A narcotização dos sentidos (MIGNOLO, 2014), colonizando o ser, o saber e o poder está posta e sem acanhamento, servindo também a naturalizar as desigualdades, pois na visão de quem domina a palavra, na modernidade, inclusive, por óbvio, no Brasil, o mundo foi feito para poucos e para os que são autorizados por esses a nele habitarem. Noutras palavras: o mundo foi feito para os que atestados são como humanos. E quem atesta? O homem único - branco e abastado.

Na perspectiva da metáfora acima, o destinatário do constitucionalismo democrático - o sujeito que sangra, geme e chora, acorrentado, por exemplo, pelo sistema de justiça criminal - é exposto ao total desamparo numa condição não humana, servindo tal a validar a premissa sobre a esquizofrenia do sistema em face daquela invenção que promoveu a expectativa de superação dos ouvidos moucos das instituições em face dessas reações hormonais do ser humano aos verbos musculares (FANON, 2005) que o degradam.

A descrição do problema gera a percepção de uma espécie de emperramento das engrenagens institucionais do sistema de justiça criminal brasileiro sob a forma, não rara, de certo cinismo hermenêutico e/ou canalhice teórica ${ }^{15}$. Sem falar das assimetrias, substratos de uma sociedade inventada, ou ontologicamente guiada, pelas hierarquias de sentidos, frustrando, inevitavelmente, as expectativas sobre igualdade, respeito e consideração (DWORKIN, 2002). Isso nos conduz para uma situação em que a pessoa herdeira da escravidão e que era o alvo do açoite, a sua descendência, no contexto atual, também empobrecida tenda a sê-lo, herdando, por conseguinte a ninguendade (RIBEIRO, 1995).

\footnotetext{
${ }^{14}$ El Color de la Razón: racismo epistemológico y razón imperial/Walter Mignolo. Trata-se uma obra compilada por Walter Mignolo, cujo conteúdo dá conta de criticar, dentre outras coisas, fundamentalmente, a Razão kantiana e hegeliana que, segundo os autores guia, ontológica e epistemologicamente, o homem a elevar-se infinitamente por sobre todas as criatura viventes na terra, inclusive, sobre outros humanos.

${ }^{15}$ Cinismo por tratar algo como se fosse o que deveria ser e que também canalhice é pelas mesmas razões indicadas. vol.13, $n^{0} .01$, Rio de Janeiro, 2020.pp.407-440 


\section{2 - A CONSTITUIÇÃO É SUBSTANTIVO E VERBO DE AÇÃO - BRISA ONTOLÓGICA E EPISTEMOLÓGICA}

Lênio Streck (2017) afirma que há muitos princípios picaretas. Esses são inventados, inclusive pelas instituições executivas da punição, ao sabor das suas pretensões, para corromperem o sistema protetor, no mínimo, desconsiderando-o, pois não temos o habitus constitucional ${ }^{16}$, não temos sentimento constitucional, parafraseando Marcelo Neves (2005).

Sousa (2019) considera que a constituição é o ponto de partida para denunciar as violações à constituição. E serve, portanto, para a afirmação de que todas as pessoas, nacionais de uma comunidade política, pertencentes são ao pacto de nação, portanto devendo serem tratadas com igual respeito e consideração. E que isso deve ocorrer, a despeito da tradição de não serem tratadas com igual dignidade.

Tudo parece ser feito para corromper ou corroer o constitucionalismo democrático, ou inviabilizar a concretude das suas normas, como se o constitucionalismo, na modernidade líquida ${ }^{17}$, ou na sociedade de consumidores (BAUMAN, 2011), tivesse sido arrastado para atrás da cortina do horizonte.

A invenção de princípios picaretas (STRECK, 2017) que carregam, no próprio ventre, a inconciliação com a constituição e com a lógica acusatória do sistema penal, e com a mínima honestidade teórica, em face dos postulados da teoria moderna do Direito, tem $o$ princípio da verdade real, no art. 156, I do CPP, como dado ilustrativo do fenômeno.

O princípio da verdade real se agasalha à cama com a interpretação prostituída ${ }^{18}$ das normas, cuja cafetinização ${ }^{19}$ se dá aparentemente pela opinião pública. Essa que de pública não tem nada, estando mais para publicada (BARRETO, 2005) por quem de fato funciona como dono do discurso.

Essa cafetinização da interpretação das normas é feita pelas estruturas opressoras, tais como o racismo e o capitalismo parasitário, ambos manejados pela mão grande do Deus Mercado. Essa suruba $^{20}$ ajuda a compreender o sadismo gozozo, por parecer produção de prazer, a perversidade do ato de interpretar, desonestamente, o Direito no âmbito da justiça criminal.

\footnotetext{
${ }^{16}$ Marcelo Neves, certamente, está parafraseando Bourdieu

${ }^{17}$ Bauman (2001) usou essa categoria teórica para marcar a diferença entre duas formas de modernidade percebida por ele: a sólida caracterizada pelas certezas e expectativas de que as promessas feitas pela modernidade se realizariam. E a líquida, referindo um tempo, cujas certezas, se liquidificaram em conjunto com as expectativas de futuro.

${ }^{18}$ Prostituição aqui se faz adequado como um termo para designar algo que de certa maneira é mercantilizado, mas, em si, não tem o perfil de mercadoria, portanto, deveria estar fora da ideia de valor de mercado.

${ }^{19}$ Metáfora que sugere a impropriedade e a desonestidade e até a crueldade de fazer mercadoria aquilo que parece impróprio de sê-lo.

20 O termo suruba é uma metáfora aqui aplicada para designar o embaralhamento e a difusão de sentidos proporcionados pela disfuncionalidade institucional no que diz respeito à função declarada do sistema penal, 
A deslegitimação do Direito Penal, inclusive, por conta de uma seletividade que lhe parece inerente, na visão de Zaffaroni (1991), somada à indecência da surubanização ${ }^{21}$ interpretativa que desconsidera a constituição, nem enrubesce as instituições que se ajoelham ao Deus Mercado.

O discurso de naturalização do capitalismo, ou no mínimo, consignando-o como método para um modo de vida que concretamente é degradante e parasitário, em face da natureza, na propaganda aparece como destino único, inspirando o ideal de enriquecer e acumular coisas em detrimento do cooperar, fomentando o competir, o explorar o espoliar, conduzindo os sentidos da sociedade para a autodestruição.

Assim é, tanto no sentido de esquizofrenizar o direito moderno, despotencializando-o para o cumprimento das suas funções declaradas, quanto no sentido do Bem Viver (ACOSTA, 2016). Esse que parece longe de nós, mas não impossível, sendo o caminho para ir ao encontro desse outro ideal, não exatamente novo, que servirá para a construção de uma memória coletiva constitucional com vistas à valorização do pertencimento territorial, tomando, por conseguinte, todas as pessoas nacionais como iguais pertencentes ao pacto de nação (SOUSA, 2019), desconstruindo o modo de vida baseado na superioridade de uns sobre os outros; na submissão da natureza aos ideais parasitários deste projeto que, em suma, representa a permanente agonia da vida.

O que temos agora é a seletividade que, paradoxalmente, na linha do pensamento Zaffaroniano, ao mesmo tempo em que seleciona fatos e sujeitos determinados para criminalizar, também tece a garantia de que o sistema penal permaneça em pé, pois sem a seletividade e a ilusão (ZAFFARONI, 1991) das agências executivas da punição, sobre a própria eficiência, no que diz respeito à punição, o sistema, fatalmente, desabaria. Sistema este estruturado na inferiorização em que as pessoas inferiorizadas não são tratadas como iguais pertencentes ao pacto de nação, mas como ninguéns!

Para ilustrar, o interrogatório, no processo penal, é um procedimento afirmado doutrinária e jurisprudencialmente como ato de Defesa, mas, concretamente, não raro, a pessoa acusada é pressionada pelo próprio juiz para que alinhe o seu discurso à narrativa acusatória. Isso feito por quem

proporcionando, por sua vez, a funcionalidade desejada no que diz respeito à sua função subterrânea que é a de afastar
os indesejáveis (Cirino, 1979). Essa é uma metáfora que visa a conotar obscenidade do sistema em face dos postulados
que sustentam a teoria moderna do direito que em termos simples podemos referir pelo menos duas: a hierarquia das
normas, tendo a constituição como guia para a interpretação e aplicação do direito e os direitos fundamentais como
ascendentes sobre tudo quanto toque o que significa o pacto de nação. O segundo refere a divisão de trabalho, invenção
da modernidade, que no caso específico do Brasil e no âmbito do sistema de justiça criminal, tem-se o sistema
acusatório que esclarece a tarefa de cada instituição no processo, porém as tarefas se misturam, prejudicando o sujeito-
alvo. Vale observar que, nessa perspectiva, isso está a denotar um desvalor, uma vez que retrata a infidelidade do
sistema, devorando os signos que constituem o direito moderno, baseado na hierarquia das normas e no ideal
democrático. Em suma: a metáfora não dispensa o significado sexual, mas visa muito mais a denotar o sistema de
justiça criminal como um monstro no sentido de corpo significante caótico muito inapropriado à teoria moderna do
direito, portanto revelando o sistema criminal como um corpo guiado pela infidelidade e promiscuidade à teoria
moderna do direito. Nesse caso havendo muito de monstruosidade no monstro. A potência subversiva de que fala
Foucault (1987) não pode operar no âmbito das instituições de Estado pois nesse caso, o monstro é monstruoso mesmo.
21 Ver nota 14 vol.13, nº.01, Riode Janeiro, 2020.pp.407-440 
tem o dever de fazer valer o pacto de nação, inscrito na constituição, inclusive no que se refere ao distanciamento imposto ao juiz em relação às partes, significa desmoralizar o próprio Direito.

Ao longo dos mais de dez anos em que a Defensoria acompanhou processos da primeira vara criminal, desde que essa era chamada de quinta, testemunhou-se muitas, muitas vezes, o juiz reclamar da Defensoria, dando como desonestidade intelectual dessa instituição a reivindicação dela para que a referida autoridade impusesse efetividade ao princípio da ampla defesa que ele, não só ignorava, mas, pior, violava.

Esse juiz reclamava do que ele chamava de "excesso de princípios constitucionais", chegando quase a expressar a reivindicação de uma norma que impusesse o princípio da ampla acusação; chamando a ausência desse, no sistema de normas, de desequilíbrio de armas, desfigurando, por conseguinte, a própria racionalidade moderna que visa a simular o Direito como uma arma de proteção, inclusive, universal.

Dessa maneira, a desonestidade, teórica e intelectual estava embutida no discurso dele, uma vez que o proferia para desmobilizar e constranger a pessoa que empunhava a defesa daquele que tomava o lugar de um vulnerabilizado, assim sendo, porque, dentre outros motivos, a pessoa que está na condição de um escolhido, perseguido e alcançado pelo sistema de justiça criminal, automaticamente foi fragilizada.

O discurso do juiz, nos termos acima, serve a demonstrar a dissonância entre a concepção do direito moderno do que seja o dever de um juiz e a sua incapacidade de compreender os fundamentos teóricos de tal dever. Conduzir o procedimento do interrogatório, como ato afirmador da Acusação, no lugar de afirmação da Plena Defesa, denota o ponto alto de fenômenos já referidos no texto: surubanização do sistema e desverbalização dos sujeitos-alvos. Esses não têm direito ao Verbo, apenas repetir o que os senhores afirmaram, sendo os seus corpos alvos e, ao mesmo tempo, único instrumento para resistirem.

Considerando que se fizer sentido a premissa maior da cosmovisão ocidental-cristã de que tudo começa com o Verbo, a desverbalização representa, no mínimo, uma existência desimportante, irrelevante, capaz de atrair, no máximo, a malvada indiferença. E considero que a efetividade da constituição é instrumental para anunciar e impor que os alvos do sistema carcerário brasileiro são recicláveis, reeditáveis, retificáveis. Talvez por isso mesmo a constituição é, no mínimo, ignorada, pois se concretizada fosse, a função não declarada do sistema, qual seja, a de afastar os indesejáveis, não se realizaria

A crítica, na sua tendência ao pessimismo, ou desencanto, parece não conseguir ultrapassar o limite que ela mesma se impôs, não conseguindo transpor a fronteira de denunciar o problema. Podese tentar desmoralizar o ideal constitucionalista como um território dos otimistas, ou iludidos, mas na 
impossibilidade de se estalar os dedos e, magicamente, superar-se todas as desonestidades teóricointelectuais e crueldades do sistema de justiça criminal, ou, simplesmente, abolir o sistema de criminalização, o que nos resta é aceitar a mão estendida do constitucionalismo democrático para nos fazer companhia durante a caminhada na direção, quem sabe, até dos abolicionismos penais.

Essa caminhada, sendo coletiva, ou devendo sê-lo, certamente desconfortará a quem intelectual e minimamente honesto seja. Não há como evitar o desconforto ético de quem tome conhecimento de que o único direito fundamental inscrito na Constituição Federal de 1988 que, concreta e plenamente, funciona é o direito à propriedade, dependendo de quem seja o proprietário, já que o pequeno proprietário de terras rurais e as pessoas que moram na periferia têm esse direito sempre violado na medida em que a sua propriedade interesse ao Deus mercado.

Por óbvio, desse desconforto não compartilharão os sentidos daqueles que, além de moldados pela estética racista e classista, herdeiros também o sejam, em linha reta, dos bens da escravidão e que permanecem na defesa de que tudo deve continuar como sempre foi.

Da outra ponta, ninguém duvida que os corpos não brancos, principalmente, os pretos, tendem a ser alvos do controle do Estado para retirá-los de circulação e conduzi-los para um não lugar, a prisão. Dada a notoriedade do fato, recorro à máxima do Direito que orienta no sentido de que sendo o fato notório, prova dispensa. Nesse sentido, espera-se que, tanto quanto o espetáculo da opressão tenha a potência de revoltar quem o assiste, nos termos de Camus (2019), os oprimidos também se revoltem com o absurdo (exploração, espoliação, submissão, parasitismo) e com as misérias que isso provoca. Superar o absurdo pressupõe encontrar sentidos.

O sentido que se faz a premissa maior é o do sentimento de dever de clamar-se por justiça. Esse devendo ser realizado não só por parte dos oprimidos, mas também por parte dos espectadores do malvado espetáculo, ressematizando a sociedade de modo que no lugar de clamar por injustiça, invoque a constituição e o que ela representa na medida dos direitos fundamentais que ela inscreve.

Se tiver razão Zaffaroni (1991), de que sem a seletividade, o sistema seria inviabilizado, noutras palavras, que a seletividade está contida na própria natureza do sistema de criminalização-penal moderno, a corrupção do sistema se faz a própria metáfora dele, se de fato da seletividade ele não puder prescindir para existir.

Essa é uma premissa válida se efetivamente a condição de iguais pertencentes da nação, honestamente, for inadmissível para sujeitos empobrecidos e negros, dado o fato de que eles são, ainda hoje, mantidos artificiosamente, e à força, do lado de fora da casa do Direito. E, considerando mais ainda a outra premissa de que efetivo tão só tende a sê-lo, ou mais, enfaticamente, o é, o direito à propriedade, há certa obviedade sobre um caminho para caber-se na definição do homem único. E isso é o mesmo que dizer: a constituição é, concretamente, para os que têm. E ter pouco não é o bastante: 
quanto mais tiver, mais perto do horizonte estás. Para os que só são, nada tendo ou pouco tendo, o direito penal é a casa feita para mantê-los sob controle. Nessa perspectiva, alinho-me ao referido mestre Juarez Cirino (1984).

Desabitados, expostos ao absurdo, sem sol (CAMUS, 2009), compreendo que autorizados estão a chutarem a porta para acessarem a Casa. Não o fazendo, pois cognitivamente dissonantes com o que lhes interessa e com o que lhes é de direito, isso por força da colonialidade de sentidos, a tendência é que antes lhes cheguem às suas portas as botas de cano longo do Estado. Sendo isso o que se revela como expectativa rotineira dos moradores das periferias das cidades brasileiras.

E, uma vez admitido que, embora na constituição todos os umbigos nela estejam fincados, mas só os de alguns são considerados nessa condição para serem tratados como sujeitos constitucionais (ROSENFELD, 2003); admitindo (não admissível) também sendo que manobras hermenêuticas ocorrem como método para disfarçar em nome de quem tais manobras são feitas, forçoso então é reconhecer que o sistema de justiça criminal brasileiro é inconstitucional. Isso não é pouco, aliás, é o suficiente para que a teoria moderna do Direito, nos termos do Kelsen (1999) seja desmoralizada fortemente.

Fácil atestar que esse texto contém, enfaticamente, denúncia sobre quem são os sujeitos-alvos da seletividade e dos dribles hermenêuticos e teóricos no ato de interpretar o Direito no território da perseguição penal do Estado. Nessa perspectiva, inevitável reconhecer que o constitucionalismo democrático, mais do que brisa, ou sopro, seria uma tempestade, fazendo tombar o sistema de justiça criminal, pois uma vez a constituição se fazendo efetivamente suprema, conforme premissa kelseniana (1999), atrapalharia a função não declarada do sistema de justiça criminalizador-penitência, qual seja, a de afastar os indesejáveis (CIRINO, 1984). Isso nos auxilia a compreender sobre o porquê de a constituição ser, no mínimo, objeto de estranhamento por parte do sistema de justiça criminal, quando não desmoralizada perante quem reivindica a efetivação dos direitos que ela anuncia.

A legitimidade do sistema penal é dissolvida nessas manobras. A constituição, que serviria para a sua mínima legitimação, é corroída por esse método de manter afastados da casa do Direito os que não se encaixam na ordem higienista (BAUMAN, 1998). Valendo também afirmar a premissa de que as questões, racial e social, ajudam a compreender essa desonesta rejeição ao constitucionalismo democrático no Brasil, embora se utilizem do Direito para manter os indesejáveis numa espécie de não-lugar.

Uma vez a constituição sendo o abrigo de todos os umbigos e isso somado ao fato de que o sistema de justiça criminal representado tende a sê-lo, ao espelho, pela imagem de um só, o homem branco e abastado, o efeito colateral dessa contradição é a dissonância cognitiva dos sujeitos e das instituições sobre o ideal da modernidade. 
A razão moderna matizou o princípio da igualdade, mas maneja, efetivamente, as garantias a partir de estigmas, de modo que os direitos de que são destinatários determinados sujeitos, materialmente, tendem a ser aqueles que, paradoxalmente, autorizam o Estado a deles retirar-lhes a liberdade e a lhes sufocar o direito à vida, portanto, inviabilizando a interpelação dos alvos preferenciais do sistema criminal na qualidade de sujeitos constitucionais, ou como pertencentes ao pacto de nação.

Para quem metaforiza o branco europeu, tudo. Para empobrecidos e herdeiros da ninguendade (RIBEIRO, 1995), parida pela escravidão e pelo racismo, o direito penal. Um leitor atento diria que essa premissa é evidentemente inválida, considerando, por exemplo, o direito do trabalho que visa a proteger os mais vulneráveis da relação trabalhista; ou o direito do consumidor que também tem a marca de pretender proteger o lado mais vulnerável da relação. Essa objeção seria inválida porque o trabalhador formalizado com seu registro em Carteira de Trabalho, desde o princípio, tratou-se de uma política destinada aos europeus que migraram para cá, não se destinando ao povo negro. E, na atual conjuntura, acabou de tombar.

Muitas são as nuances que explicam a cassação dos direitos trabalhistas no Brasil, via reforma trabalhista, aprovada em Emenda à Constituição brasileira, no ano de 2018. Valendo considerar as resistências havidas que, inclusive garantiram a própria existência, por algumas décadas, desse direito que garantia o mínimo de proteção ao sujeito empregado.

O fato é que a descrição acima demonstra que, nem o direito trabalhista, nem o do consumidor, no Brasil, dão sentido à invalidação da premissa de que o direito penal é uma política inventada para afastar os desencaixados da ordem (BAUMAN, 1998). Essa é menos a jurídica e, mais, muito mais, a racial e a econômica. E dúvida não pode haver de que as garantias constitucionais servem de ferramenta principal da luta por direitos, tanto por isso é, quando menos, ignorada pelo sistema de justiça criminalizador e penitência.

Nessa linha, parece inconciliáveis, a constituição e o sistema de justiça criminal, pois a primeira derrubaria o último com apenas um sopro $^{22}$. E aplicar a constituição, no âmbito da justiça criminalizadora, seria um pequeno passo para a resistência à ontologia eurocêntrica num dos aspectos mais ilustrativos que representa o sistema de justiça criminal brasileiro, dado o manejo desse para degradar, corromper, violar, crudelizar, enfim, inferiorizar, inclusive, coisificando os sujeitos que, avistados ao espelho, não representam o homem único, qual seja, o branco e abastado.

Em consequência disso, a constituição se revela um instrumento que tem a potência de nos conduzir numa trilha que diferente seja daquela sobre a qual sempre caminhamos; a que pavimentada

\footnotetext{
${ }^{22}$ Vera Regina Pereira de Andrade palestra ministrada no Curso de Especialização em Direitos Humanos Esperança Garcia em 01/04/2017. Módulo I - Direitos Humanos, Sistema de Justiça e Criminologia. Na cidade de Teresina-PI.
} 
foi e continua sendo pelos ossos, e sangue, e lágrimas dos que foram e são ditos estranhos, inferiores, incivilizados, enfim, não humanos, sem alma. Isso, se por um lado causaria o espanto da vergonha, por outro, a redenção merecedora, mais de misericórdia e, menos, de vingança, pois que essa, sendo, por sua vez, filha do ressentimento, só serve a retroalimentar a guerra fratricida.

Com toda essa potência, o pacto de nação, em termos de Estado Democrático e de Direitos, é um risco para o projeto de homem único, uma vez que, se efetivado fosse, esse perderia a condição de utopia a que todos devem almejar, nos termos da colonialidade, para outra coisa alimentada de outros sentidos: a condição de sujeitos constitucionais, pessoas cidadãs, iguais pertencentes ao pacto de nação.

Ora! Parece contraditório propor que a constituição pode ser instrumentada para a resistência ontológica ao engodo da modernidade, nos seus termos seletivos, hierarquizadores e parasitários de sentidos. Mas essa objeção só seria válida se a constituição, como conjunto de disciplina, ou normas de convivência, fosse uma invenção da modernidade. Mas onde há mais de uma pessoa, há constituição de sentidos com potencial de conflito (SOUSA, 2020). E por isso mesmo regras são postas, ou para evitá-los, ou para consertá-los. Portanto, antes da modernidade, muito antes, ou, desde sempre, constituição houve para disciplinar a convivência e o elo de 02, ou mais. Robson Crusoé e o Sexta Feira (DEFOE, 2011), que o digam.

O cinismo teórico, do qual faz parte a própria seletividade do sistema de justiça criminalizador, funciona como uma forma de manutenção do sistema penal que, não cumprindo a sua função declarada $^{23}$ é um sucesso da sua função ideologicamente garantidora do controle social sobre as pessoas consideradas desclassificadas, excedentes ou até o chorume social (BAUMAN, 2005).

Mas se tem razão o jurista argentino (ZAFFARONI, 1991) sobre a ilegitimidade do sistema de justiça penal e sobre o fracasso da sua função declarada (prevenir crime e ressocializar quem o cometeu), por sua vez, Juarez Cirino (1984) também o tem sobre a funcionalidade absoluta do sistema, no que se refere à sua função subterrânea, qual seja, a de afastar os diagnosticados como indesejáveis.

O constitucionalismo democrático foi o que de melhor foi parido pela modernidade, tão padrasta $^{24}$. No modo de vida moderno, ela é, no mínimo, uma leve brisa, também sendo o guia, a lanterna e a mão e o machado para resistir ao cinismo do sistema penal, tendo a mão direita, testando o pulso da esquerda para sentir se algo ainda nesse lateja em termos de pacto de nação: no sentido de que os sujeitos se sintam afetados por esse laço de unidade.

\section{3 - ENTRE AS MISÉRIAS E O SOL}

\footnotetext{
${ }^{23}$ Juarez Cirino. As raízes do Crime. 1984. Editora Forense. Rio de Janeiro

${ }^{24}$ Num sentido convencional de que padrasto não protege, o que faria um pai.
} 


\section{Quaestio Iuris}

vol.13, $\mathrm{n}^{0} .01$, Riode Janeiro, 2020. pp.407-440

DOI: $10.12957 /$ rqi.2020.50969

No momento estamos sufocados pela sensação de que a única permanência é a impermanência; pelo desespero de viver com a tragédia sob a forma de desejo; pela impossibilidade de conciliar verdade e generosidade; pela convivência com a dor como única verdade acessível; com a certeza mais trágica que substituiu a certeza de outrora, qual seja essa, a de que a dor viria e, agora, a de que ela embora nunca irá. Some-se o desespero de outras incertezas certas: de que a morte não traz felicidade; nenhuma desconfiança sobre o que substituirá o tempo e o espaço depois da morte. Nesse quadro trágico, impossível admitir algum território sem essas sensações aterradoras como guias dos nossos desejos.

A modernidade foi estruturada para tal fim de modo que as pessoas se mobilizem pela infelicidade, uma vez que, permanentemente, buscando, em tempos inexistentes, ou porque já passado, ou porque futuro, o que não se tornará presente, porque se vier a tornar-se presente, não será percebido, já que o olhar estará voltado, principalmente, para o futuro.

Considerando então que o absurdo se revela com mais potência, do que o sol, desqualificando o direito moderno como uma invenção, por si só, capaz de reencantar o mundo, pois com baixíssima potência para cumprir as suas ambiciosas promessas, precisamos desesperadamente reinterpretar o nosso mundo e nós mesmos a fim de que nos guiemos também por lógicas baseadas em outros meios e modos de vida.

Há marcadores que foram ressemantizados a partir de outras cosmovisões como, Bem Viver e filosofias africanas, que têm a potência de nos proporcionar a saída de um estado de coisas, para um estado de sujeitos.

Para o estado de coisas fomos arrastado pela modernidade. Essa nos iludiu sobre uma imposta superioridade humana em relação à natureza, nos descolando da condição de parte dessa, para sujeitos à parte da natureza, isso a fim de nos conduzir a um modo de vida, cujos verbos são: acumular, controlar, submeter, enriquecer, competir, consumir, dentre outros que, em suma, significam destruir. O problema se fez mais aterrador ainda porque esses verbos se estendem à relação entre os humanos, significando a submissão, ou a inferiorização de uns sobre os outros por meio do projeto moderno de racialização. E no lugar de cooperar, amparar, acolher, se impõe, latejantemente, o verbo aniquilar.

A comunidade política e a afirmação das pessoas como iguais pertencentes a essa comunidade representam uma invenção para corrigir esse ideal de superioridade de uns sobre os outros de modo que todos sejam interpelados como sujeitos constitucionais porque autores do pacto de nação.

Os enfrentamentos em face do projeto de racialização, ou de inferiorização de uns sobre outros, não devem se apresentar como soluções mágicas, ou messiânicas. Os esforços devem ser no sentido de produzir fissuras, ainda que pequenas, na totalidade ontológica e epistêmica que impôs o modelo eurocêntrico de vida para o mundo todo, nos termos, por exemplo, de um despreendimento epistêmico (MIGNOLO, 2014). 


\section{Quaestio Iuris}

vol. 13, $n^{\circ} .01$, Riode Janeiro, 2020. pp.407-440

DOI: $10.12957 /$ rqi.2020.50969

Isso inclui buscar outras experiências de resoluções de conflitos, que tematizem o conflito de modo que a dor e o doído sejam levados em consideração, transcendendo o punitivismo estéril que ao tempo em que não serve para prevenir crime, sendo essa uma das funções declaradas do sistema, concretamente, fomenta mais ainda a quebra dos laços sociais que o conflito enseja.

Esse fenômeno é mais ainda incrementado num contexto em que o pacto de nação, delineado os seus termos na constituição, levado em conta não é para pautar o percurso institucional das agências executivas de punição, conceitualmente, representando a violência institucional e fomentando também a violência social.

Como dito, nos termos do Zaffaroni (1991), impossível a relegitimação do sistema. Difícil fazer objeção válida a essa premissa, pois o sistema se esconde no ventre da única forma de legitimação aparentemente manejada, o cinismo hermenêutico, a canalhice teórica, via surubanização de sentidos.

O sistema penal moderno não desaba por causa da força do seu chaveco ${ }^{25}$. Esse se revela na promessa mais desleal dele em face do próprio direito moderno, cuja faceta mais desgarrada da totalidade epistêmica moderna, é o constitucionalismo democrático.

Refiro-me ao chaveco que promete afastar os consumidores falhos, os indesejáveis, ou seja, todos os que se equiparem, metafórica, ou literalmente, à condição de negros libertos no final do século XIX que, formalmente, nem serviam mais para terem o corpo explorado até a morte, portanto, inviáveis como consumidores. Em suma, naquela ocasião, considerados foram como inservíveis para se encaixarem na categoria de trabalhadores assalariados, pois quem foi considerado adequado para ocupar, naquele momento, o lugar de trabalhador assalariado foram as pessoas brancas europeias migradas para o Brasil. E, menos ainda proprietários poderiam ser os libertos, dado que a Lei de Terras impediu-lhes dessa condição, marcando, historicamente, a morbidade, ou malvadeza (RIBEIRO, 1995) que parece característica dos sentidos do povo brasileiro.

Em suma: genuflexo às estruturas opressoras, principalmente, racismo e capitalismo, que funcionam simbioticamente, o sistema de justiça criminal legitima a sua função subterrânea. Essa que, sem dúvida, é muito mais popular (socialmente clamada) do que a declarada, pois a promessa daquela é de eliminação imediata, do meio social, daqueles que identificados sejam como indesejáveis, dispensando repetir quem assim é considerado. E a sociedade brasileira parece cada dia mais afiar os dentes contra os que com essa cara lhes são apresentados.

\footnotetext{
${ }^{25} \mathrm{O}$ manejo dos meios de comunicação se dá como propaganda em favor do sistema abusivo realizado em forma de espetáculo, expondo o alvo alcançado como inimigo, sendo, curiosamente, os próprios alvos os que tendem a mais se embevecerem do ódio que ressoa desse grotesco espetáculo das mídias que o veiculam. Aliás, isso serve a afiar os dentes dos pobres contra os pobres; a inviabilizar a unidade política cidadã; a fomentar o clamor social por vingança que serve a substituir o clamor por justiça social, essa constitucionalmente inscrita. Servindo também ao desvalor da memória que alimenta a ação política. Enfim, serve a fragilizar os laços comunitários. É uma espécie de repetição de discurso de desvalor: assédio moral permanente e que desenha, ou serve de ilustração, de como a comunicação social é instrumentada pelo fenômeno da colonialidade do ser, do poder e do saber.
} 
Aliás, curiosamente, nos termos dos sentidos produzidos pela opinião pública, que parece ser a quem gozozamente se vê alinhado ao sistema de justiça criminal, o processo criminal, conforme a constituição, ou até menos ainda, alinhado pelo menos aos procedimentos formais, inscritos infraconstitucionalmente, tende a ser estranhado, ignorado, pois não sendo o sujeito da perseguição punitiva considerado como destinatário de proteção constitucional, ou enlaçado pelo grande pacto, o processo, na visão majoritária, é para cumprir a sua função não declarada referida em parágrafos anteriores.

Nessa perspectiva, exigir que o sistema seja funcional, do ponto de vista do que declara ser o seu destino, não raro e, curiosamente, desagrada, ou é estranhado até, ou principalmente, por quem tem a missão de fiscalizar o cumprimento ou a aplicação da lei, pois o espetáculo referido produz uma leitura no sentido de que respeitar os direitos fundamentais seria uma espécie de idolatria ao bandido, uma bandidolatria.

Isso serve a sugerir que a comunidade política brasileira, nação, ou a sociedade, como queira, sendo uma abstração, cujo sangue que exibe nos próprios dentes não é dela, e sim do sujeito que deveria ser protegido de abusos, no âmbito de um processo criminal, não reconhece a identidade do sujeito constitucional na perspectiva de que deve sim se submeter às leis exatamente por ser delas o autor. (HABERMAS, 1997).

Essa percepção equivocada sobre o significado de uma comunidade política pode ser configurada pelo processo de coisificação, ou desumanização desse sujeito-alvo. Fenômeno esse que se apresenta como uma dança trágica entre a sociedade e as instituições, pisoteando o pacto de nação.

A constituição e suas garantias, como pontos de chegada desta análise, pelo sistema penal olhadas são, no máximo, de soslaio. É claro que no percurso de qualquer dissecação do sistema de justiça criminalizador-penitência, inevitável é encarar a teoria crítica, ou a criminologia que agasalha a crítica com ardor. Aliás, isso está ilustrado pelas categorias teóricas manejadas até então para esta análise. Mas não posso deixar de esclarecer que entre a utopia dos abolicionismos penais e o constitucionalismo democrático, aparentemente ao alcance das teorias críticas do Direito, alinho-me ao sonho do último. Aliás, o desencanto com o pacto de nação retroalimenta as malvadezas e afasta a constituição do projeto de resistência ontológica.

Essa visão, de certa maneira, reconhece a funcionalidade da constituição para uma relegitimação, ou legitimação do sistema, não admitida pela crítica sem a perspectiva de construção da pacificação da comunidade política. Mas dado que a colonialidade mantém as estruturas firmes a ponto de promover a desilusão e o fracasso das lutas descolonizadoras, a ideia é que a totalidade epistêmica seja feita objeto de pequenas e incessantes fissuras, pois está dado que as revoluções armadas que pretendiam o rompimento com essa totalidade epistêmica frustrou os revolucionários, pois sem a 
revolução das premissas do pensar, as estruturas opressoras da modernidade permanecerão sustentando a colonialidade do saber, do poder, do ser (MIGNOLO, 2014).

O pacto de nação inscrito na constituição de 1988, no Brasil, pode servir de percurso para atingir os fins pretendidos pela crítica que prefere, em grande parte das vezes, se limitar ao diagnóstico. A constituição é enunciadora de uma unidade nacional. E, nesse sentido, a luta para a sua concretude é solar, atualmente, sendo essa menos até do que utopia, dada a miséria do autoritarismo que está a nos desanimar.

Curiosamente, a crise que acomete à defesa de uma comunidade política democrática constitucional demanda reação política para superá-la. Mas adestrados quanto somos pela colonialidade dos nossos sentidos (do saber, do ser, do poder), difícil trazer à mesa aquele elemento imprescindível para a ação política, noutras palavras, sair do estado de coisas para o estado de sujeitos.

Refiro-me à percepção de que só na condição de sujeito a pessoa é capaz de perceber o engodo da modernidade; que, uma vez conseguindo perceber a força da colonialidade sobre si, tornando-se, por conseguinte, sujeito, se reconhecerá como um pertencente ao pacto, cujo enlace a todos deve abarcar; que o povo se constitui de uma unidade que é constituída por cada um em particular, mas enlaçados todos são como pertencentes ao pacto de nação; que o compromisso constitucional resultante do pacto de nação deve igualar politicamente a todos.

Em suma: sem o avistar de muitos na mesma direção, amalgamados pela percepção de que sofrem do mesmo mal - da coisificação/inferiorização eurocêntrica - impossível ação política para a efetivação dos termos do pacto que promoveu a constituição. Essa no sentido de afetação e pertencimento.

O sistema de justiça criminal é permanentemente afeito e exposto à completa desmoralização, inclusive quando a sociedade conta com ele para resolver um problema que só pode ser resolvido se o Estado e a sociedade, dentre outras coisas, cumprirem o objetivo da república inscrito no artigo $3^{\circ}$, inciso III, da Constituição Federal de 1988, erradicando a pobreza e diminuindo as desigualdade sociais. Portanto, a disfuncionalidade e a esquizofrenia são as marcas do sistema de justiça criminalizador em todos os seus termos.

Evidentemente, o propósito não é uma macro revolução, mas de mudança gradativa no enfrentamento do que conforma a nossa existência. A revolução, em si, é inconciliável com o sentido de rompimento que é próprio do ato de revolucionar sem a percepção de que a utopia do homem único é uma invenção dos outros, não nossa, portanto, deve-se dá em nível de ontologia e epistemologia de modo a romper o adestramento promovido pelo projeto eurocêntrico de modernidade.

Revolucionar é verbo intransitivo, prescindindo de objeto, de predicado e de predicativo. O sentido da revolução é ela mesma, e a crítica denota isso quando não consegue, na maioria das vezes, 


\section{Quaestio Iuris}

vol. 13, nº.01, Riode Janeiro, 2020. pp.407-440

DOI: $10.12957 /$ rqi.2020.50969

ultrapassar a fronteira da denúncia. Ela se encerra em si mesma. Talvez por isso seja tão difícil para a crítica imaginar alternativas para percorrer outros caminhos na direção do sol e alcançá-lo concretamente.

Os ressentimentos produzidos pelas inferiorizações, degradações, desvalor, ou categorização dos sujeitos em termos de raça, classe, dentre outros tantos marcadores, tendem a produzir, dentre muitos sintomas de fissura social, a desesperança, a raiva sentida de novo, mas não, necessariamente, de modo incessante, ou permanente, uma vez que em espiral. Essa, por sua vez, alimentada e desenhada por ritos que descascam as feridas da crueldade caracterizadora do sentido da nação brasileira, se faz premissa maior validada, ilustrativamente, pela escravidão e o mal-estar que se revela em inúmeros sintomas coletivos dos quais padecem todos: uns sob a forma de feridas que jamais sararam, ou quando sim, só aparentemente, pois debaixo da casca há pus que lateja, ou deveria latejar, sob a forma de revolta.

Isso tende a minar o percurso para a pacificação social fraturada pelas opções políticas da segunda metade do século XIX. Essas opções ilustradas são pelo cinismo inscrito no artigo $1^{\circ}$ da Lei de Terras de 1850 referida. As consequências se inscrevem nos ritos agônicos de uma urbanidade desassossegada. Esses ritos espreitam nas esquinas das ruas nas grandes cidades e nos becos das periferias adoecidas de sentidos. Esses, por sua vez, perdidos na fenda que desconectou as gentes do que poderiam ter sido e vivido porque um destino mais socialmente justo lhes foi interditado pela desterritorialização, desde que os seus ancestrais, mais consanguíneos, foram arrastados à força de África para cá.

A paz e o amalgamento ético-político entre as pessoas dependem de intenções de assim construir entre elas. E para isso o sentimento de pertencer a uma mesma nação é chave para alcançar o pretendido, mas as negativas da intenção, seja como ação, seja como comunicação e como sentimento, são o espectro que alimentam o desejo de não enlace. E isso sufoca qualquer pretensão de enroscar-se ao outro, inclusive, politicamente, o que demanda outra memória coletiva de nação, em que heróis e heroínas se desprendam, ontológica e epistemologicamente, do ideal do homem único, branco e abastado.

Na perspectiva acima é necessário que nos museus, nos livros didáticos conste o heroísmo negro e indígena; que neles seja contada também a participação de não brancos na construção da nação de modo que a razão e a dignidade não sejam guiadas pela ideia de cor e de classe; que outros modos de ser e de viver e de sentir sejam considerados tantos válidos, quanto encantadores; que o espetáculo da opressão, no lugar do encanto promovido pela colonialidade, desperte revolta epistêmica.

As nossas misérias se inscrevem no modelo do medo do outro, não na confiança. Isso é fratura, é afastamento, é fenda. E a lei de terras, nos termos acima, muito explica a gênese da nossa preferência 
pelos verbos romper, quebrar, fraturar, separar, no lugar dos verbos, amparar, acolher, enlaçar, abraçar. Essa opção do legislador inspirado na escravatocracia, até hoje, mais do que latente, permanece inspirando fortemente práticas de injustiças, cujo sintoma mais escandaloso e indecentemente evidente, é a desigualdade social e o encarceramento em massa da população negra.

A Lei de Terras, nas poucas linhas do seu artigo primeiro, produziu a base para a demarcação do absurdo que representa o nada para a maioria do povo brasileiro e o sol somente para poucos. E isso vem sendo reproduzido de modo sofisticado, ou não, até hoje.

Nessa linha, o sistema penal é a metáfora desse absurdo, servindo a nos manter permanentemente atentos sobre quem somos. Considero que as quase 800 mil pessoas encarceradas, no Brasil, representam a nossa face mais cruel, pois uma nação que precisa encarcerar tanta gente, e tantas mais que ela acha que deveriam também sê-lo, por achar que aquela quantidade ainda é pouca, sadia não é. Dispensando lembrar que as misérias do sistema, entre essas as reveladas nos corpos dos seus prisioneiros, servem de amostragem sobre quem somos e o quanto longe do sol estamos.

Darcy Ribeiro tem muito a nos guiar para deduzir o porquê. Num texto, cujo título é: sobre o óbvio (RIBEIRO, 1995), ajuda-nos a compreender como a elite brasileira sempre manejou tudo de modo a falsear a realidade para atingir os seus objetivos, manipulando, seduzindo e confundindo a sociedade sobre as causas dos nossos problemas relativos à inferiorização, pobreza, desigualdades e até sobre a nossa própria identidade. E isso alimenta a desconfiança que nos impede de pactuar uma nação de sentidos densos e tenazes, cujo pêndulo se direcione para a justiça social.

Nessa caminhada, a constituição parece ainda não ter seduzido o povo brasileiro suficientemente para fazer dela o seu habitus (BOURDIEU, 1989). E, considerando que a sedução dos ideais de mercado, que substituiu a sociedade de produtores pela de consumidores (BAUMAN, 2011), bateu à porta da nação antes da hegemonia da sedução do constitucionalismo democrático, difícil ser otimista, mas por outro lado, uma vez a fratura estando exposta, o que se espera é, senão a cura, no mínimo, o tratamento.

Ainda não estamos certos e seguros sobre a cura para o problema descrito, mas desconfiamos do que possa ser o tratamento: recorrer ao novo constitucionalismo latino americano; à experiência do Bem Viver, ao Ubuntu; à justiça restaurativa dos indígenas; ao constitucionalismo democrático, enfim, apostar na permeabilidade dos sentidos a todos os mundos possíveis e que signifiquem afetar-se por práticas de restauração de laços; não de rompimentos; de alívios; não de dor. Enfim, de vida, não de morte.

A constituição sendo o território onde moram todos os umbigos ${ }^{26}$, constitui-se de uma lógica que contraria a compreensão brasileira sobre o fundamento das desigualdades como processo natural,

\footnotetext{
${ }^{26}$ Umbigo aqui faz referência a um dito popular de que cada pessoa se importa com seu próprio umbigo. 
sendo verdadeiramente filhas da inferiorização de determinadas identidades que não representem a metáfora desse homem branco e abastado.

A pobreza da grande maioria e a extrema riqueza de poucos no Brasil é um dos sintomas mais malvados, cuja causa mais aparente é um processo social e cultural racista e classista que a promoveu sem sequer enrubescer os que dele se aproveitaram e se aproveitam para compor o lugar dos privilegiados por tal processo. Não considerar também o racismo como causa das desigualdades e que essas se realizam praticamente como projeto de nação (FANON, 2005) significa sucumbir ao disfarce das suas verdadeiras causas.

Se tinha razão Fanon (2005), sobre o fato de que o colonizado tem sonhos musculares, no sentido de que quando adormece os seus pesadelos são sempre verbo de ação: correndo; sendo perseguido; defendendo-se, o fato de a pessoa negra e empobrecida, no Brasil, ter que fazê-lo com os pés descalços, desarmados, esfarrapados enquanto o colonizador, seu verdadeiro inimigo, lhe persegue de botas, sapatos e, não raro, coturnos, torna mais fácil compreender que a violência no Brasil pode também ser explicada como sintoma fratricida.

A colonialidade nos venda os sentidos, pois não enxergamos os nossos algozes - aqueles que, ardilosamente, inventaram a utopia do homem branco e acumulador, impondo-a como modelo único de civilização a todos, configurado no projeto eurocêntrico que foi feito para nunca nele nos encaixarmos, mas que somos incapazes de assim percebê-lo.

Se nos termos de Dworkin (1999), a constituição é a melhor narrativa que há de um povo e, por conseguinte, de uma nação, infelizmente, no Brasil, o sistema carcerário é a nossa face mais feia e que se apresenta sob a forma de encarceramento em massa, servindo a retratar a nossa malvadeza característica, cujos sentidos de nação parecem guiados pelos donos do Verbo que nem sequer coram ao pisotearem a maioria com os seus sapatos polidos, ou botas de longo cano por onde espirra o sangue de tantos e o padecimento de muitos mais, denotando o de sempre: o mundo do absurdo, ou das misérias, para muitos, o sol para poucos.

O que explica nunca chegar a hora para o clamor ético por mais justiça social, aliás, prevista constitucionalmente, cujos instrumentos para realizá-la estão dispostos na Constituição Federal de 1988 e que, antes mesmo da experiência de se terem efetivos, atacados são como, por exemplo, os direitos trabalhistas e a seguridade social? Isso não significa um descuido para aquilo que não dizem, mas têm como certo ou, no mínimo, intuem: que o ressentimento dos desamparados, de quem nada tem a perder, é temerário?

Aliás, o sistema penal no Brasil parece ser o sintoma mais perverso da força verbal, quase exclusiva, do homem branco e abastado e que alimenta-se das questões social e racial, tendo da colonialidade o instrumento poderoso para iludir os desvalidos, ao mesmo tempo, crudelizando-os e 
os distraindo para garantir a permanência das estruturas e dos privilégios de poucos e o total desamparo de quase todos, mantendo-os na desverbalidade. Sem Verbo, resta o vazio. Esse, por sua vez, é feito para caber algo tão grande quanto uma invenção do tamanho de Deus. Entre isso e nada, melhor o vazio!

Mas há outra coisa que dentro desse vazio do tamanho do Deus também cabe: o ressentimento, pois Deus desamparou o homem e a mulher com o livre arbítrio. Dostoievski (2013), pela boca do personagem Ivan Karamazov, um dos irmãos parricidas, diz que é o ressentimento contra Ele que guia a humanidade e também a vontade de superar essa pesada liberdade, na primeira oportunidade havida.

A Lei de Terras de 1850, cuja culpa não é só do Euzébio de Queiroz, mas, principalmente, de quem ele representava, seguindo o plano da lei de 1848, que recebeu dele o nome próprio, é uma espécie de livre arbítrio editada pelos homens no plano abaixo do céu. Por causa dessa Lei, coube aos libertos uma liberdade desesperadora, dado que não tinham para onde ir, nem podia ficar. E de terra, só o pedaço que coubesse os seus pés descalços, isso forçando-os a não interromperem o gerúndio do seu perambular, ou substituí-lo por qualquer verbo no infinitivo, ou conjugado.

Em face de quem os pés descalços da escravidão no Brasil, compreensivelmente, deveriam ressentir? Quem é a metáfora do Todo Poderoso, nesse caso? Qual a origem desta linguagem violenta que amargamos no Brasil? Por que os alvos do ressentimento parecem ser injustamente pessoas com as quais todos os ressentidos, herdeiros dessa ninguendade, em verdade, deveriam se unir? Por que essa linguagem violenta, de regra, é acionada por pessoas empobrecidas contra outras também na mesma condição, ou contra si mesmas, considerando que, no final das contas, violentar um irmão, ainda que metafórico seja esse, é dirigir a violência contra si mesmo, considerando, mais ainda, que um pertencente de uma nação é irmão de pacto de um outro pertencente? Esse aparente sadomasoquismo tem alguma relação com a desterritorialidade histórica que marcou o germinar da sociedade moderna brasileira, composta, no seu ponto de partida, por sujeitos coisificados, uns porque retirados à força do útero africano para virem para cá, enriquecer os primeiros malvados, outros e que aqui já estavam, mas foram arrancados dos braços da mama ou da pachamama que os guardava e alimentava?

O ressentimento dos herdeiros da ninguendade é legítimo. Seus sonhos musculares o justificam. O problema é que o engodo sobre quem humano e civilizado seja tem morada nos nossos próprios sentidos de colonizados. E sendo a farsa manietada por quem dispõe do Verbo, a tendência é a promoção eficaz do disfarce sobre quem deveria ser o alvo desse ressentimento, sendo, não raro, em termos micro e literais, o vizinho, ou a vizinha que pegou o menino, que virou algoz, no colo, ou quaisquer sujeitos, que na lógica da verticalização de sentidos, minorizado possa sê-lo. Isso denotando uma guerra fratricida! 


\section{Quaestio Iuris}

vol.13, $\mathrm{n}^{0} .01$, Riode Janeiro, 2020. pp.407-440

DOI: $10.12957 /$ rqi.2020.50969

Para as instituições, inclusive o judiciário, que deveriam funcionar como garantidores da efetividade dos direitos fundamentais, está de acordo com o clamor social por encarceramento, ou padecimento, parece-lhe mais vantajoso do ponto de vista egóico. E sendo a ética coisa para inglês ver, estar de acordo com as ruas, que já manipuladas, ou adestradas foram pelos vícios da colonialidade, significa estar de acordo com o espírito do tempo, muito mais importante do que seguir os juramentos feitos para a plateia.

A disfuncionalidade institucional e social no Brasil, além de herança cultural e histórica da desonestidade teórico-intelectual e da autofagia, que se inscreve no próprio processo de disfuncionalidade, parece se explicar, em alguns dos seus termos, na legislação que funcionou, por exemplo, por meio da pena do Euzébio de Queiroz para prevenir, em face dos negros que em futuro bem próximo seriam libertos, a possibilidade de viverem com o mínimo de dignidade. E repisando: a lei de terras de 1850 , principalmente no seu artigo $1^{\circ}$, funcionou muito eficazmente para isso.

Euzébio era uma espécie de ministro da justiça mais preocupado em promover os interesses de quem representava o Capital parasitário na época, cujo trono estava fincado em Londres, do que as consequências evidentes, também para a época, que adviriam, uma vez impondo que aos libertos só lhes restassem de espaço para habitarem, e outros verbos, aquilo onde os seus pés descalços coubessem.

Perambulando por estradas e veredas, essa malvadeza e ingratidão deve ter sido muito remoída por suas vítimas. E as quase 800 mil pessoas encarceradas hoje no Brasil podem ser consideradas como um fenômeno que tanto ilustra a malvadeza atualizada de quem Euzébio de Queiroz funcionou como preposto, quanto a aparente impossibilidade de construção de laços afetivos e de comunidade, no sentido político do termo, entre os herdeiros da ninguendade e da branquitude (PIZA, 2005). Nessa linha, são perceptíveis os contornos referidos como arquitetura do projeto de modernidade que construiu esse processo tão violento e tão difícil de exterminar.

Nessa perspectiva, não é de se estranhar que a violência, as desigualdades, a pobreza são o chorume que constituem as principais substâncias da nação brasileira. Essa, desde sempre, por ter-se edificado com base na crueldade e na espoliação de determinados povos, permeabilizou o destino inevitável: o medo do outro.

Portanto, a canalhice diretamente pode até ter sido do Euzébio de Queiroz, mas ele representava a metáfora de quem, até hoje, repete o parasitismo e a espoliação dos mundos: o homem único, ou branco e abastado

Para esclarecer, embora pareça dispensável, a Lei de Terras de 1850 , no artigo $1^{\circ}$, prescrevia que a única forma de aquisição da terra era a compra. Isso inviabilizou o acesso àquela por parte das pessoas negras, por isso largadas, mulambunizadas e sem ter para onde irem, nem ficarem, depois de formalmente ter-se deslegalizado a escravidão, a condição deles foi a de sem destino, sem lugar, 
desverbalizados, inexistidos: desterritorializados, ou sem útero para desejarem o eterno retorno.

De alguém empurrado à força para esse não lugar, cujos dentes do algoz riam cheios de sangue e de pele dos ninguenzados, honestamente não se deve esperar ausência de ressentimento, pois se não bastasse a condição de escravos que amargaram, até então, o desprezo e a covardia se repetem até hoje. O problema é que não conseguem tirar a venda que lhes colocaram sobre os olhos a respeito de quem são os seus algozes. Uma venda que é mantida por ensinamentos maternos e paternos, escolares, universitários, pela cultura do entretenimento, músicas, filmes, novelas, piadas e tudo o mais que formam a ética e a estética.

A pergunta que ressoa com força dessa descrição que serve a marcar, ou caracterizar o povo brasileiro é: quem hoje representa o Euzébio de Queiroz? E quem atualmente, no Brasil, é herdeiro dos efeitos de tamanha covardia? Quem hoje representa os ninguenzados, os desverbalizados, os mulambunizados?

Se o leitor concorda que Euzébio representava esse cinismo e crueldade até hoje postos aos 400 talheres, servidos por personagens herdeiros de papeis que se assemelham, ou, no mínimo, os metaforizam, legitima a extensão do adjetivo para as instituições (sistema de justiça criminalizador) que hoje representam tais personagens sem nem sequer disfarçarem. E se o mesmo leitor concorda sobre quem foram os alvos de tamanha covardia e herdeiros também do ressentimento produzido por tal covardia, ressentir deve ser compreendido como sintoma de re-volta. E assim sendo, de onde se poderá tirar a justificativa para o clamor social por mais e mais encarceramento, ao invés de clamor por justiça social? Dependendo da resposta, somos todos cínicos.

Aliás, a referida desconexão cognitiva da sociedade brasileira sobre a sua própria identidade sobre como, o quê e quando foi forjada - culminando no desleixo sobre os direitos fundamentais e, pior: até o desprezo por esses, certamente, se explica, dentre tantas coisas, porque tais direitos impõem reconhecer, ao se avistar o espelho do Brasil, outras identidades e que estas sejam tidas, essencialmente, como valor, superando aquela imagem única de homem branco e abastado, essa que se apresenta, ardilosamente, como destino único.

A descrição que compõe este texto denota o Absurdo que a própria modernidade produz, como, por exemplo, a seletividade do sistema de justiça criminal, mas, ao mesmo tempo, prometendo resolver todos os problemas. Uma arrogância epistemológica que embaralha o caminho para o Sol. Aliás, talvez mais do que embaralhar, labirintiza-o.

As misérias da vida moderna, incluindo o processo penal, parafraseando, tanto Carnelluti (2013), quanto Camus (2008), são o ponto de partida para se pensar num mundo que deseje superálas. Mas dado o fato de que a sociedade tem sido incitada, especialmente, pelos meios de comunicação de massa a afiar os dentes contra si mesma, numa espécie de suicídio político e filosófico que tanto 
assustava Camus (2008), o punitivismo serve de pedra de amolar esses dentes. Isso nos dá o sinal para que fiquemos muito atentos, também, à sabedoria de fora dos livros, por exemplo, na oralidade que representa um pensamento livre e onde moram os sentidos afetos às ancestralidades que nos aliviam das misérias.

O culto ao punitivismo é uma dessas misérias. O constitucionalismo democrático deve representar para nós o Sol, ou a nossa própria utopia. E a constituição, substrato do constitucionalismo, tanto contém a memória inscrita no DNA dos pactos feitos sob a confiança da palavra, quanto os feitos sob a confiança da escrita. A constituição federal brasileira de 1988 ilustra o último modelo. E o pacto de nação nela inscrito garante os direitos fundamentais.

Preferir, concretamente, a miséria que representa o encarceramento em massa, ao clamor ético por justiça social, denota um problema que certamente a colonialidade de nossos sentidos o explica, o que não nos desresponsabiliza de tematizar a questão para quem sabe seja pauta das refeições familiares, das salas de aula, seja na escola, seja na universidade, na música. Quem sabe isso não se torne uma estética e, portanto, um habitus constitucional, um sentimento de pertencer a uma comunidade política com igualdade de direitos políticos em que todas as pessoas se sintam iguais pertencentes ao pacto de nação.

\section{CONSIDERAÇÕES FINAIS}

O texto serviu ao propósito de refletir sobre os herdeiros do Euzébio de Queiroz, que materializou-se sob a forma de projeto de lei alinhado aos interesses eurocêntricos, definindo quem teria lugar - os de pele retinta receberam como herança o legado do não lugar, por conseguinte, do não ser, do não pertencer. Essas pessoas não podem dispor do Verbo, da palavra para expressar o que sentem; o que pensam; o que desejam fazer, cabendo-lhes apenas repetir os interesses do projeto europeu e que são tratados, por conseguinte, como não pertencentes ao pacto de nação. São eles destinatários do padecimento provocado pela criminalização, pois a única lei da qual são, concretamente, destinatários é a que os envia para a prisão.

As pessoas que herdaram o legado da dor e do sofrimento foram literalmente amordaçadas e atualmente são amordaçadas pela colonialidade do saber, do poder e do ser. Os seus desejos são os mesmos de quem lhes amordaçam, por isso funciona muito bem a repetição do capitão do mato que, ferindo a sua própria pele, ajuda a materializar o projeto eurocêntrico ao custo da sua dor própria e a 


\title{
Quaestio Iuris
}

vol.13, nº.01, Riode Janeiro, 2020. pp.407-440

DOI: $10.12957 /$ rqi.2020.50969

do seu irmão de cor. E, diante disso, a única saída é construir outras ideias, outros sonhos e a nossa própria utopia que nos sirva a enfrentar o referido padrão que se repete há mais de quinhentos anos.

Acima há uma proposta de retificação. Mas isso depende do esforço reparador da palavra, de modo que, discursivamente, as pessoas atentem para o fato de que uma vida sem a possibilidade escolhas, sendo esse o caso dos feitos ninguéns, merece a compreensão sobre os ressentimentos fatalmente produzidos por tal fenômeno. E o reparo dessa ordem, que reverencia os absurdos e as misérias, é diretamente proporcional à nossa disposição de falar sobre isso, honestamente, para reivindicar, eticamente, tal reparo em face da narrativa de injustiças inscrita na memória, pois a Revolta com o espetáculo da opressão e, principalmente, provocada pela memória, atual ou ancestral, daqueles que submetidos foram e são por esse espetáculo grotesco se constitui de uma dívida ética e coletiva

Um ponto de partida deve ser o de denunciar tanto a violação dos direitos dos iguais pertencentes ao pacto de nação, quanto o desrespeito aos direitos fundamentais, considerando serem esses estranhados ou ignorados pelo sistema criminalizador brasileiro, quando não pior ainda, ficando de fora, como parece ser o caso do território da execução de penas, cuja jurisdicidade funciona mais ainda precariamente, nos termos ilustrados por meio desta análise.

A ideia é criar discursividade que forme entendimentos de outra ideia de comunidade política com valorização do território brasileiro e dos nossos pertencimentos territoriais de modo que a narrativa penetre os espaços onde é formatada a visão que nos orienta. E talvez consigamos formar um entendimento de nação construída por iguais pertencentes, de modo que a nossa Constituição se torne a melhor poesia, estética e narrativa de nós mesmos com uma Constituição levada a sério.

\section{IS IT EUZÉBIO DE QUEIROZ'S FAULT?}

\begin{abstract}
This article analyzes the feat of Euzébio de Queiroz in the Land Law and the ways in which the justice institutions treat people from the exclusion produced by the referred law, to thematize and demonstrate that this issue reflects on another not so debated: the interpellation of said target subject as belonging to the nation pact. In other words: the black subject tends not to be treated with the consideration that an author of the constitution deserves. The guiding question is: how to face the constitutional disenchantment of impoverished and black people within the criminal justice system? With the indication of denouncing the violations, with a view to building another understanding of the nation. The text was produced as a literature review through analytical categories guiding the production of the discursive itinerary. The result was a diagnosis of the performance of the criminal system, whose discussion focused on the structure that serves to make fundamental rights invisible in the criminalizing system, indicating ways of confrontation with the strength to build other understandings of the political community, constitutionalism and nation pact that serve, in turn, to promote the sense that all nationals are equal belonging and so challenged should be.
\end{abstract}


KEYWORDS: constitution, coloniality, racism, mass incarceration, constitutional subject

\section{BIBLIOGRAFIA}

ACOSTA, Alberto. O bem viver: uma oportunidade para imaginar outros mundos. Tradução de Tadeu Breda. São Paulo: Autonomia Literária, Elefante, 2016.

ADORNO, Theodor. Teoria estética. São Paulo: Martins Fontes, 1982.

ANDRADE, Vera Regina Pereira de. Direitos Humanos, Sistema de Justiça e Criminologia. Palestra ministrada no Curso de Especialização em Direitos Humanos Esperança Garcia em 01/04/2017. Módulo I - Direitos Humanos, Sistema de Justiça e Criminologia. Teresina : 2017.

ASSIS, Machado de. Obra Completa. Rio de Janeiro : Nova Aguilar 1994. v. II.

ASSIS, Machado de. Volume de contos. Rio de Janeiro : Garnier, 1884.

ASSIS, Machado de. Dom Casmurro. Volume 1. Nova Aguilar: Rio de Janeiro, 1994.

ASSIS, Machado de. Quincas Borba. São Paulo: Ática, 1980 (Série Bom Livro).

BARRETO, Lima. O Triste Fim de Policarpo Quaresma. São Paulo: DCL, 2005.

BARRETO, Lima. Recordações do escrivão Isaías Caminha. São Paulo: Edusp, 2017.

BAUMAN, Zygmunt. O Mal Estar da Pós-modernidade. Rio de Janeiro: Jorge Zahar, 1998

BAUMAN. A ética é possível no mundo de consumidores? Rio de Janeiro: Editora Zahar, 2011.

BAUMAN. Modernidade Líquida. Rio de janeiro: Jorge Zahar, 2001.

BAUMAN. Vidas Desperdiçadas. Rio de Janeiro : Editora Zahar, 2005.

BAUMAN. Capitalismo Parasitário. Rio de Janeiro: Editora Zahar, 2015

BENTHAM, Jeremy. Uma Introdução aos Princípios da Moral e da Legislação. "Os Pensadores", trad. Luiz João Baraúna. São Paulo, 1979.

CAMUS, Albert. O homem revoltado. Tradução de Valerie Rumjanek.- $13^{\mathrm{a}}$ Ed. - Rio de Janeiro: Record, 1999.

CAMUS, Albert. O Mito de Sísifo - Ensaio sobre o absurdo. Rio de Janeiro: Editora Record, 2008.

CARNELUTTI, Francesco. As misérias do processo penal. São Paulo: Roussel Editores, 2013.

CIRINO, Juarez. As Raízes do Crime - um estudo sobre as estruturas e as instituições da violência. Editora Forense; Rio de Janeiro, 1984.

DARWIN, C. A Origem das Espécies. Trad. Joaquim de Mesquita Paul, 2003. Disponível em http://ecologia.ib.usp.br/ffa/arquivos/abril/darwin1.pdf. Acesso 26 de fevereiro de 2020.

DEFOE, Daniel. Robinson Crusoé. São Paulo: Companhia das Letras (em associação com a Penguin Classics). Trad. de Sergio Flaksman; introdução e notas de John Richetti, 2011.

DOSTOIEVSKI, Fiodor. Os irmãos Karamazov. Tradução Herculano Villas-Boas. São Paulo: Editora Martin Claret, 2013.

DWORKIN, Ronald. Levando os direitos a sério. Trad. Nelson Boeira. São Paulo: Martins Fontes, 2002.

DWORKIN, Ronald. O império do direito. Trad. Jefferson Luiz Camargo. São Paulo: Martins Fontes, 1999. 
FANON, Franz. Os Condenados da Terra. Juiz de Fora : Editora da UFJF, 2005.

Foucault, Michel. Vigiar e punir: nascimento da prisão; tradução de Raquel Ramalhete. Petrópolis, Vozes, 1987.

FREUD, Sigmund. Pulsões e destino da pulsão. In: Obras Psicológicas de Sigmund Freud. Rio de Janeiro : Imago, 2004.

GARAPON, Antoine. O juiz e a democracia: o guardião das promessas. 2. ed. Rio de Janeiro: Revan, 1999.

GIAMBERARDinO, André. Curso de Penologia e Execução Penal: 1. ed. Florianópolis: Tirant, 2018

HABERMAS, Jürgen. Direito e Democracia: entre facticidade e validade . Rio de Janeiro: Tempo Brasileiro, 1997.

HEGEL, G. W. F. 1992. Fenomenologia do Espírito - Partes I e II. Tradução Paulo Meneses.2 ${ }^{\mathrm{a}}$ Edição. Petrópolis : Editora Vozes.

KELSEN, Hans. Teoria Pura do Direito. São Paulo : Martins Fontes, 1999.

LARA, Silvia. Legislação sobre escravos africanos na América portuguesa. In:

ANDRÉSGALLEGO, José (Dir./ Coord.). Nuevas aportaciones a la historia jurídica de iberoamérica. Madrid: Fundación Histórica Tavera, 2000.

MIGNOLO, Walter D. Colonialidade - o lado mais escuro da modernidade. In: Revista Brasileira de Ciências Sociais - RBCS vol.32 no.94 São Paulo, 2017. Epub June 22, 2017.

MIGNOLO, Walter D. et al. El color de la razón: racismo epismológico y razón imperial. Ciudad Autónoma de Buenos Aires : Del Signo, 2014.

NEVES, Marcelo da Costa Pinto. A força simbólica dos direitos humanos. Revista Eletrônica de Direito de Estado. Salvador, n. 4,

p. $1-35, \quad$ out./nov./dez. $2005 . \quad$ Disponível em: $<$ http://www.direitodoestado.com.br/artigo/marceloneves/a-forca-simbolica-dos-direitoshumanos>. Acesso em: 26 de fevereiro de 2020.

PIZA, Edith. Adolescência e racismo: uma breve reflexão. An. 1 Simp. Internacional do Adolescente May. $2005 . \quad$ Disponível em: http://www.proceedings.scielo.br/scielo.php?pid=MSC0000000082005000100022\&script=sci _arttext. Acesso 26 de fevereiro de 2020.

ROGERSON, Barnaby. O profeta Maomé. Uma biografia. Trad. Lis Alves. Rio de Janeiro / São Paulo: Record, 2004.

ROSENBAUM Yudith. A ética na literatura: leitura de "Mineirinho", de Clarice Lispector. Estud. av. vol.24 no.69 São Paulo 2010 http://www.scielo.br/scielo.php?script=sci_arttext\&pid=S010340142010000200011

RIBEIRO, Darcy. O Povo Brasileiro: A formação e o sentido de Brasil. $2^{\mathrm{a}}$ ed. São Paulo: Companhia das Letras, 1995.

RIBEIRO, Darcy. Sobre o obvio - Ensaios Insólitos. Porto Alegre: Editora L\&PM, 1979.

SARTRE, Jean-Paul. As palavras. Tradução J. Guinsburg. Rio de Janeiro : Nova Fronteira, 2005.

SOUSA, Maria Sueli Rodrigues de. Pertencimento territorial como liberdade: direito e política como unidade na resistência quilombola por pertencimento territorial. In: GOMES, Rodrigo Portela. 
Constitucionalismo e Quilombos: famílias negras no enfrentamento ao racismo de Estado. Rio de Janeiro : Editora Lumen Juris, 2019.

STRECK, Lenio Luiz. Dicionário de hermenêutica: quarenta temas fundamentais da teoria do direito à luz da crítica hermenêutica do direito. Belo Horizonte: Letramento: Casa do Direito, 2017.

ZAFFARONI, Eugenio. Em busca das penas perdidas, trad. Vânia Romano Pedrosa e Amir Lopes da Conceição. Rio de Janeiro: Revan, 1991.

Trabalho enviado em 14 de maio de 2020

Aceito em 19 de maio de 2020 